\title{
Agroclimatic conditions in Europe under climate change
}

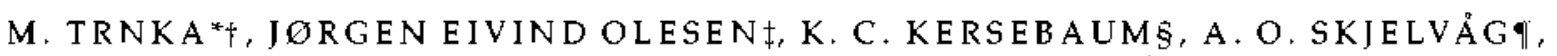

J. EITZINGER\|, B. SEGUIN**, P. PELTONEN-SAINIO $\dagger$, R, RÖTTER $\dagger$, ANA IGLESIAS柿,

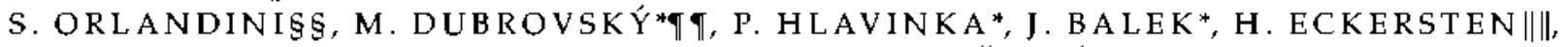

E. CLOPPET**, P. CALANCA ††

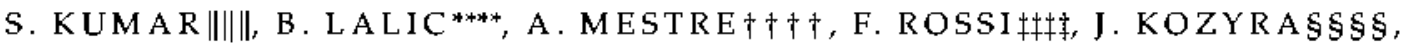

V. ALEXANDROV $\mid \pi \rrbracket \pi$, D. SEMERÁDOVÁ* and Z. ŽALUD*

${ }^{*}$ Institute of Agrosystems and Bioclimatology, Mendel Universify in Bno, Zennedelska 1, Brno 613 00, Czech Republic, $\uparrow C z e c h G$ lobe - Center for Global Climate Change Impacts Studies, Poř́č́ 3b, 60300 Brno, Czech Republic, \$Department of Agroecology and Environment, Faculty of Agricultural Sciences, Aarhus Unizersity, Blichers Allé 20, DK-8830 Tjele, Denmark, §Leibniz-Center of Agricultural Landscape Research, Institute for Landscape Systems Antalysis, Eberswalder Str. 84, D-15374 Müncheberg, Germany, - Department of Plant and Envirommental Sciences, Norwegian University of Life Sciences, PO Box 5003, N-1432 Ås, Nonvay, ||Department of Water, Amosphere and Enviromment, Institute of Meteorology, University of Natural Resources and Applied Life Sciences (BOKU), Peter-Jordan Str. 82, A-1190 Vienta, Austria, **INRA, Mission changement climatique et effet de serre, site Agroparc, domaine Saint-Paul, 84914 Avignon Cedex 9, France, $\dagger \uparrow M T T$ Agrifood Research Finhand, Plant Production Research, FI31600, Jokioinen and FI-50100, Mikkeli, Fintand, 拉Deparment of Agricultural Economics and Social Sciences, Universidad Politécnica de Madrid (UPM), Avenida de la Complutense sn, 28040 Matrid, Spain, §§Department of Plant, Soil and Environmental Science, University of Florence, Piazzale delle Cascine 18, 50144 Firenze, Italy, q|Institute of Atmospheric Physics, Czech Academy of Sciences, Bočni II-1401, 14131 Prague, Czech Republic, |||Sveriges Lantbruksuniversitet, Institutionen för wäxtproduktionsekologi, PO Box 7043,750 07 Uppsala, Siveden, ${ }^{* * *}$ Météo-France, Direction de la Production, Division d'Agrométéorologie du département Services, 42, Avenue G. Coriolis 31057, Toulouse Cedex, France, $\uparrow+\uparrow$ Agroscope ReckenholzTänikon Resarch Station, Air Pollution and Climate Group, Recketholzstr. 191,8046 Zürich, Switzerland, \$łłEnvironnental Modelling Unit, Flenish Institute for Technological Research, Boeretang 200,2400 Mol, Belgium, \$\$SAgrometeorological Department, Meteorological and Hydrological Service, Gric 3, 10000 Zagreb, Croatia, "था $\|$ Slovak Hydrometeorological Institute, Jesenioza 17, 83315 Bratislava, Slovakia, ||||||Department of Geography, National University of Ireland, St Amnes, North Campus, Maynooth, Co. Kildare, Ireland, ${ }^{* * * *}$ Faculty of Agriculture, University of Novi Sad, Dositej Obradovic Sq. 8, 21000 Novi Sad,

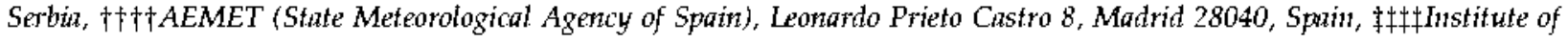
Biometeorology, National Resenrch Council, Via P. Gobetti 101, 40129 Bologna, Italy, \$\$\$\$Institute of Soil Science and Plant Cultivation - State Research Institute in Pulawy, Czartoryskich 8, 24-100 Pulaury, Poland, ๆ and Hydrology, 66 Tzarigradsko shose Blvd., BG-1784 Sofia, Bulgaria

\begin{abstract}
To date, projections of European crop yields under climate change have been based almost entirely on the outputs of crop-growth models. While this strategy can provide good estimates of the effects of climatic factors, soil conditions and management on crop yield, these models usually do not capture all of the important aspects related to crop management, or the relevant environmental factors. Moreover, crop-simulation studies often have severe limitations with respect to the number of crops covered or the spatial extent. The present study, based on agroclimatic indices, provides a general picture of agroclimatic conditions in western and central Europe (study area lays between $8.5^{\circ} \mathrm{W}-$ $27^{\circ} \mathrm{E}$ and $37-63.5^{\circ} \mathrm{N}$ ), which allows for a more general assessment of climate-change impacts. The results obtained from the analysis of data from 86 different sites were clustered according to an environmental stratification of Europe. The analysis was carried for the baseline (1971-2000) and future climate conditions (time horizons of 2030, 2050 and with a global temperature increase of $5^{\circ} \mathrm{C}$ ) based on outputs of three global circulation models. For many environmental zones, there were clear signs of deteriorating agroclimatic condition in terms of increased drought stress and shortening of the active growing season, which in some regions become increasingly squeezed between a cold winter and a hot summer. For most zones the projections show a marked need for adaptive measures to either increase soil water availability or drought resistance of crops. This study concludes that rainfed agriculture is likely to face more climate-related risks, although the analyzed agroclimatic indicators will probably remain at a level that should permit rainfed production. However, results suggests that there is a risk of increasing number of extremely unfavorable years in many climate zones, which might result in higher interannual yield variability and constitute a challenge for proper crop management.
\end{abstract}




\section{Introduction}

Climate change is expected to affect both regional and global food production through changes in overall agroclimatic conditions (e.g. Fischer et al., 2005; Solomon et al., 2007). The observed warming trend throughout Europe $\left(+0.90^{\circ} \mathrm{C}\right.$ from 1901 to 2005) is wellestablished (Alcamo ef al., 2007); however, precipitation trends are more spatially variable, wherein mean winter precipitation has increased in most of the Atlantic and northern Europe (Klein Tank et al., 2002) but has changed little in Central Europe (e.g. Brázdil et al., 2009). Furthermore, trends are negative in the eastern Mediterranean, and no significant change has been observed in the west (Norrant \& Douguédroit, 2006). According to Alcamo et al. (2007), the effects of climate change and increased atmospheric $\mathrm{CO}_{2}$ levels by 2050 are expected to lead to small increases in European crop productivity, but temperature increases greater than approximately $2{ }^{\circ} \mathrm{C}$ would likely lead to declines in the yields of many crops (Easterling et al., 2007). Several climate projections for 2050 exceed this $2{ }^{\circ} \mathrm{C}$ threshold (Giorgi \& Lionello, 2008).

Although different studies have resulted in different projections, all agree on a consistent spatial distribution of the effects, leading to the need for the regionalization of adaptation policy (Ciscar et al., 2009; COM, 2009). The projected increase in extreme weather events (e.g. periods of high temperature and droughts) over at least some parts of Europe is predicted to increase yield variability (Jones et al., 2003; Porter \& Semenov, 2005; Lavalle et al., 2009; Quiroga \& Iglesias, 2009; Iglesias et al., 2010). Technological development (e.g. new crop varieties and improved cropping practices) could ameliorate the effects of climate change (Ewert et al., 2005; Peltonen-Sainio et al., 2009a). However, there is evidence of a slowing rate of yield growth, either due to the closing of the yield gap between realized and potential yields (e.g. Cassman et al., 2003; Ewert et al., 2005; Lobell et al., 2009), or due to policies such as stricter environmental regulation (e.g. Finger, 2010).

To date, there have been a linited number of reports (Kenny \& Harrison, 1993) dealing with the changes expected in agroclimatic parameters at the pan-European scale, and many of these are review articles (Olesen \& Bindi, 2002; Lavalle ot al., 2009; Olesen et al., 2011). Conversely, various indications may be found in global-scale analyses that display the consequences of climate change for the whole of Europe considered as one large region (IFPRI, 2009) or two large entities (Parry et al., 2004); these two studies directly estimated crop-yield changes using empirically calibrated crop-simulation models. They also provided quantitative estimates; however, these are linked to a fixed set of hypotheses intended to depict the key components of world crop production. Alternative approaches have considered sets of agroclimatic indices, with varying degrees of complexity (e.g. Fisher et al., 2002, 2005; Ramankutty et al., 2002). The latter studies offer comprehensive views of changes for Europe. However, these studies have had to rely on monthly datasets, whereas many key processes in agrosystems take place on daily and even shorter time scales. Therefore, the idea of elaborating an accessible and flexible tool allowing for the assessment of agroclimatic conditions (including the roles of variability and extremes) while keeping in mind the approaches being used has been progressively developed. Herein, we present a study aimed to provide a quantitative evaluation of agroclimatic conditions under present and projected climate-change conditions over most of the $\mathrm{EU}$ and neighboring countries with a special focus on variability and events with lower probability. For this purpose, we selected and applied a set of $\mathbf{1 1}$ agroclimatic indices to a new dataset of daily climatic data representing key agricultural regions of Europe.

\section{Methods}

\section{Study area and data}

The current stndy was confined to datasers of daily weather observations provided by members of the COST734 network. The data cover the period from 1971 to 2000 and were taken from weather stations representing the key agricultural regions of the given conntries and provide continnous daily data, inclnding maximnm and minimnm temperatures, global radiation (or sunshine duration), precipitation, mean daily relative air humidity and wind speed. In addition, these stations (when possible) were located outside urbanized areas. Such requirements significantly reduced the number of suitable sites, especially considering that all of the sites with $<95 \%$ coverage (for each separate element) were exclnded from the analysis. The inclnded sites (Fig. 1) were then gronped according to their presence within particular environmental zones $(\mathrm{EnZ})$ as defined by Metzger ef al. (2005) and Jongman et al. (2006). The EnZ definitions herein cover 13 zones (Fig. 1) comprising 84 environmental strata (EnS), which are classified by monthly minimum and maximnm temperatures, sum of 


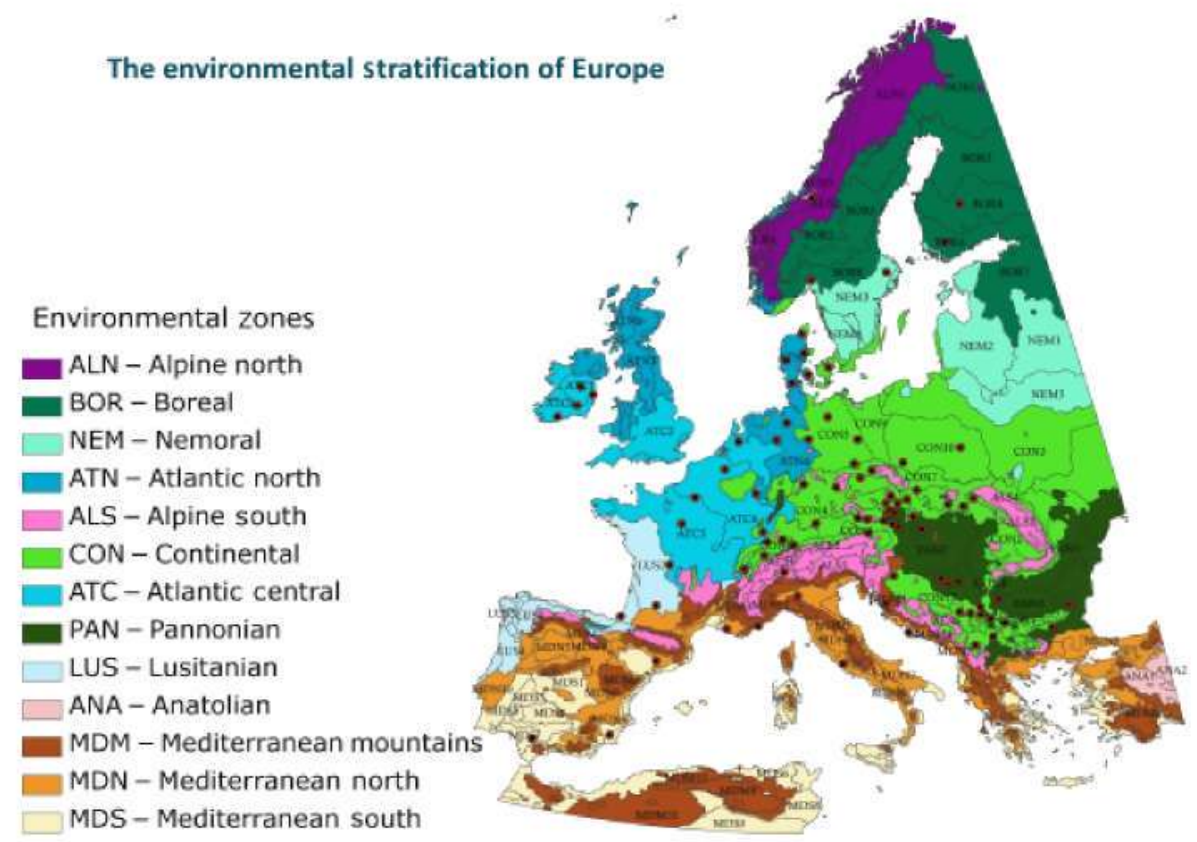

Fig. 1 EnZs in Europe according to Metzger et al. (2005) and Jongman et al. (2006) and sites where data were collected for the COST 734 database. The complete list of sites can be found in Appendix S1. Among the 13 EnZs, only the Anatolian zone was not considered because it is not technically located on the European continent; the Mediterranean mountains (MDM) and the Alpine north (ALN) zones were each represented by only one site.

precipitation, percentage of sunshine in months representing the four seasons (January, April, July and October) together with altitude, slope, northing and oceanicity. Overall, the strata accounting for $72 \%$ of all European agricultural land were represented by at least one climate station (Table 1). To simplify the figures, only the mean values for each EnZ are presented. To limit possible bias caused by the uneven representations of EnS, results were first averaged for each individual EnS and these means were used for the calculation of EnZ values.

Complete data were collected from 86 carefully screened sites from a total of 137 provided sites (Appendix S1), and the study domain covered the area between $8.5^{\circ} \mathrm{W}-27^{\circ} \mathrm{E}$ and $37-$ $63.5^{\circ} \mathrm{N}$. Nineteen European states are represented in the database, including the major agricultural producers of the $\mathrm{EU}$; however, several important countries and regions (e.g. the eastern Mediterranean) were not covered due to a lack of data from these areas.

\section{Agroclimatic indices}

Figure 2 provides an overview of the methodological approach of using indicators for the evaluation of changes in agroclimatic conditions in Europe under climate change. To describe agroclimatic conditions, the 11 indicators described in Tables $2 \mathrm{a}$ and $2 \mathrm{~b}$ were selected from a plethora of available options to represent the potential effects of weather on crop productivity and management. The selection was made from a 'short-list' of approximately 120 indices. The final set of indicators was required not only to represent potential productivity and growing conditions but also field workability as well as the occurrence of extreme events relevant to agriculture. This includes impacts as well as adaptation options for the different agricultural sectors. The study further focused on late frost and drought, as they were identified as major problems across most of Europe (Olesen et al., 2011). In addition, each of the selected indices had to be applicable across all of the sites and be calculable from available datasets; furthermore, the portfolio was chosen so as to complement rather than repeat previous studies.

The daily reference $\left(\mathrm{ET}_{\mathrm{r}}\right)$ and actual $\left(\mathrm{ET}_{\mathrm{a}}\right)$ evapotranspiration values were calculated using the Penman-Monteith approach, as described in Allen et al. (1998), using modifications validated by Hlavinka et al. (in press). Crop growth on a given day was considered not to be significantly limited by water if the daily ratios of $\mathrm{ET}_{\mathrm{a}}$ to $\mathrm{ET}_{\mathrm{r}}$ exceeded 0.4-0.5 (FAO, 1979; Fisher et al., 2002; Eliasson et al., 2007). To limit eventual overestimation of water shortage, the lower end of the range (0.4) was applied here. The temperature thresholds used rely on the works of Chmielewski \& Köhn (2000), Mitchell \& Hulme (2002) and Larcher (2003), and were similar to those used by Fisher et al. (2002).

The Huglin index represents the thermal suitability for wine production and includes a correction factor for latitude as described by Huglin (1978). This index allows for characterizations of the suitability of viticulture in general and particular grapevine cultivars at a given location. A constraint of this index is that it does not consider cold-temperature limitations, which are critical for continental climates, and other 
Table 1 Overview of the COST 734 database. The agricultural areas in the European states presented in Fig. 1 are based on the Corine land cover CLC2000-9/2007 and a $100 \mathrm{~m}$ resolution (copyright EEA, Copenhagen, 2007*). Only areas with agricultural land consisting of strata that contained at least one weather station were included in this study

\begin{tabular}{|c|c|c|c|c|c|c|c|}
\hline EnZ name & $\begin{array}{l}\text { EnZ } \\
\text { acronym }\end{array}$ & $\begin{array}{l}\text { Agricultural } \\
\text { area in } \\
\text { the EnZ† } \\
\text { (ha) }\end{array}$ & $\begin{array}{l}\text { Share of } \\
\text { agricnltnral } \\
\text { area of } \\
\text { total area } \\
(\%)\end{array}$ & $\begin{array}{l}\text { Agricultural } \\
\text { area } \\
\text { represented } \\
\text { by the } \\
\text { database } \\
(\%)\end{array}$ & $\begin{array}{l}\text { Nnmber } \\
\text { of } \\
\text { stations }\end{array}$ & $\begin{array}{l}\text { Number of } \\
\text { strata } \\
\text { represented/ } \\
\text { total number } \\
\text { of strata }\end{array}$ & Countries in the En $Z_{t}^{+}$ \\
\hline Alpine north & $\mathrm{ALN}$ & 691600 & 2.1 & 50 & 1 & $1 / 4$ & FI, NO, SE \\
\hline Boreal & BOR & 6480306 & 7.8 & 38 & 2 & $2 / 8$ & BY, EE, FI, LV, NO, RU, SE \\
\hline Nemoral & NEM & 10836063 & 21.8 & 18 & 2 & $1 / 5$ & BY, EE, FI, LV, LT, NO, PL, RU, SE \\
\hline Atlantic north & ATN & 16642613 & 57.1 & 70 & 6 & $2 / 5$ & $\mathrm{DK}, \mathrm{DE}, \mathrm{GB}, \mathrm{IE}, \mathrm{IM}, \mathrm{NL}, \mathrm{NO}$ \\
\hline Alpine south & ALS & 6040069 & 20.0 & 74 & 2 & $2 / 6$ & $\begin{array}{l}\text { AD, AL, AT, BG, BA, CH, CZ, DE, } \\
\text { GR, ES, FR, HR, IT, MK, ME, PL, } \\
\text { RO, RE, SI, SK, UA }\end{array}$ \\
\hline Continental & $\mathrm{CON}$ & 57900681 & 46.4 & 96 & 36 & $10 / 12$ & $\begin{array}{l}\text { AL, AT, BG, BY, BE, BA, CH, CZ, } \\
\text { DE, DK, FR, HR, HU, LV, LI, } \\
\text { LT, LU, MK, MD, ME, NL, NO, } \\
\text { PL, RO, RS, RU, SE, SI, SK, UA }\end{array}$ \\
\hline Atlantic central & ATC & 40180988 & 79.4 & 100 & 13 & $5 / 5$ & BE, CH, DE, ES, FR, GB, IE, LU, NL \\
\hline Pannonian & PAN & 27392881 & 65.1 & 73 & 13 & $2 / 3$ & $\begin{array}{l}\text { AT, BA, BG, CZ, DE, GR, FR, HR, } \\
\text { MK, HU, MD, RO, RS, SI, SK, UA }\end{array}$ \\
\hline Lusitanian & LUS & 11031181 & 56.5 & 83 & 2 & $2 / 4$ & ES, FR, PT \\
\hline $\begin{array}{l}\text { Mediterranean } \\
\text { monntains }\end{array}$ & MDM & 8922394 & 16.4 & 4 & 1 & $1 / 11$ & $\begin{array}{l}\text { AL, BA, BG, CH, GR, ES, FR, HR, } \\
\text { IT, MK, HU, ME, PT, SI }\end{array}$ \\
\hline $\begin{array}{l}\text { Mediterranean } \\
\text { north }\end{array}$ & MDN & 26560575 & 50.7 & 32 & 4 & $3 / 10$ & $\begin{array}{l}\text { AL, BA, BG, GR, ES, FR, HR, } \\
\text { IT, MK, ME, PT, SI, TR }\end{array}$ \\
\hline $\begin{array}{l}\text { Mediterranean } \\
\text { south }\end{array}$ & MDS & 21214125 & 37.4 & 71 & 4 & $4 / 9$ & AL, ES, FR, GR, IT, MT, PT \\
\hline
\end{tabular}

*http://wwweea.europa,eu

tData from Fig. 1.

$\ddagger$ Countries at least partly included in the zone are identified by internet country code.

\section{Estimating the main changes in crop conditions derived from changes in climate}

\begin{tabular}{|c|c|}
\hline $\begin{array}{l}\text { Potential biomass and crop } \\
\text { development } \\
\text { (indicator a) }\end{array}$ & $\begin{array}{l}\text { Water deficit during growing } \\
\text { season that may be the } \\
\text { result of drought }\end{array}$ \\
\hline $\begin{array}{l}\text { Period suitable } \\
\text { for crop growth } \\
\text { Temperature suitable for } \\
\text { grape growth } \\
\text { Low temperature limitations } \\
\text { (indicators b-d) }\end{array}$ & $\begin{array}{l}\text { Sowing conditions } \\
\text { Harvesting conditions } \\
\text { (indicators } g-k \text { ) }\end{array}$ \\
\hline
\end{tabular}

\section{Assessment of agroclimatic conditions in Europe under climate change}

Fig. 2 Overview of the methodological approach to using indicators for the evaluation of changes in agroclimatic conditions in Europe under climate change. limitations such as sunshine duration, soil conditions and water availability. Local climatic variations based on orography may also alter these conditions significantly.

The thresholds for sowing and harvest suitability (Table 2a) were based on published literature and tested using the observed sowing and harvest dates for spring barley, winter wheat and maize at 30 experimental stations at in the Czech Republic over a period of 20 years. The approach nsed is broadly in agreement with similar studies by Leenhardt \& Lemaire (2002) and Maton et al. (2007). The soil-moisture thresholds used to define the suitable days for sowing and harvesting were stricter than those used by Rounsevel] (1993) and Cooper et al. (1997), as no soil compaction or soil-structure damage should occur in sustainable agricultural systems. Across all of the investigated sites, the sowing and harvesting windows were held constant despite the varying relevance of some of these windows.

The agroclimatic parameters listed in Tables $2 a$ and $2 b$ were calculated with the use of a software package, AGRICLIM (Trnka et al., 2010a), which is available from the anthors. For all of the $\mathrm{ET}_{\mathrm{r}}$ and $\mathrm{ET}_{\mathrm{a}}$ calcnlations, spring barley was used as 
Table 2a Overview of the indices used in the study

\begin{tabular}{|c|c|c|c|}
\hline Agroclimatic factors & Indicator name (units) & Indicator description & Symbol \\
\hline $\begin{array}{l}\text { Potential biomass and crop } \\
\text { development }\end{array}$ & $\begin{array}{l}\text { Sum of effective global radiation } \\
\qquad\left(\mathrm{MJ} \mathrm{m}^{-2} \text { season }^{-1}\right)\end{array}$ & $\begin{array}{l}\text { Sum of global radiation of days with daily mean } \\
\text { temperature }>5^{\circ} \mathrm{C} \text {, daily minimum } \\
\text { temperature }>0^{\circ} \mathrm{C}, \mathrm{ET}_{a}^{*} / \mathrm{ET}_{\mathrm{r}} \dagger \text { ratio }>0.4 \text { and } \\
\text { no snow cover } \ddagger\end{array}$ & a \\
\hline $\begin{array}{l}\text { Time period suitable for } \\
\text { crop growth }\end{array}$ & Sum of effective growing days (days) & $\begin{array}{l}\text { Number of days with daily mean temperature } \\
>5^{\circ} \mathrm{C} \text {, daily minimum temperature }>0^{\circ} \mathrm{C} \text {, no } \\
\text { snow cover and an } \mathrm{ET}_{\mathrm{a}} / \mathrm{ET}_{\mathrm{r}} \text { ratio }>0.4\end{array}$ & $\mathrm{~b}$ \\
\hline $\begin{array}{l}\text { Temperature suitable for } \\
\text { grape growth }\end{array}$ & Huglin index (unitless) & $\begin{array}{l}\text { Thermal suitability for grape production, for the } \\
\text { period from } 1 \text { April to } 30 \text { September }\end{array}$ & $c$ \\
\hline $\begin{array}{l}\text { Low temperature } \\
\text { limitations }\end{array}$ & $\begin{array}{l}\text { Date of the last frost [date (from } \\
\text { January 1st)] }\end{array}$ & $\begin{array}{l}\text { Last occurrence of a daily minimum temperature of } \\
<-0.1{ }^{\circ} \mathrm{C} \text { in the given season before June } 30 \text { th }\end{array}$ & $\mathrm{d}$ \\
\hline $\begin{array}{l}\text { Water deficit during } \\
\text { growing season that }\end{array}$ & $\begin{array}{l}\text { Number of days with water deficits } \\
\text { from April to June (days) }\end{array}$ & $\begin{array}{l}\text { All days within the given period with } \mathrm{ET}_{\mathrm{a}} / \mathrm{ET}_{\mathrm{r}} \\
\text { of }<0.4\end{array}$ & $\mathrm{e}$ \\
\hline $\begin{array}{l}\text { may be the result of } \\
\text { drought }\end{array}$ & $\begin{array}{l}\text { Number of days with water deficits } \\
\text { from June to August (days) }\end{array}$ & Same as e & f \\
\hline \multirow[t]{2}{*}{ Harvesting conditions } & $\begin{array}{l}\text { Proportion of suitable days for } \\
\text { harvesting in June (unitless) }\end{array}$ & $\begin{array}{l}\text { All days with soil-water content in the top } 0.1 \mathrm{~m} \\
\text { between } 10 \% \text { and } 70 \% \text { of the maximum soil } \\
\text { water-holding capacity (SWC), with } \\
\text { precipitation on the given day } \leq 1 \mathrm{~mm} \text { and } \\
\text { precipitation on the preceding day } \leq 5 \mathrm{~mm}\end{array}$ & $g$ \\
\hline & $\begin{array}{l}\text { Proportion of suitable days for } \\
\text { harvesting in July (unitless) }\end{array}$ & Same as $\mathrm{g}$ & $\mathrm{h}$ \\
\hline \multirow[t]{3}{*}{$\begin{array}{l}\text { Sowing conditions that } \\
\text { will affect the growing } \\
\text { season }\end{array}$} & $\begin{array}{l}\text { Proportion of suitable days for } \\
\text { sowing from March 1st to April } \\
\text { 25th (early spring) (unitless) }\end{array}$ & $\begin{array}{l}\text { All days with soil-water content in the top } 0.1 \mathrm{~m} \\
\text { between } 10 \% \text { and } 70 \% \text { of the maximum soil } \\
\text { water-holding capacity (SWC), mean daily } \\
\text { temperature on the given day and on the } \\
\text { preceding day }>55^{\circ} \mathrm{C} \text {, without snow cover and } \\
\text { with precipitation on the given day } \leq 1 \mathrm{~mm} \\
\text { and precipitation on the preceding day } \leq 5 \mathrm{~mm}\end{array}$ & $\mathbf{j}$ \\
\hline & $\begin{array}{l}\text { Proportion of suitable days for } \\
\text { sowing from April 26th to May } \\
\text { 20th (late spring) (unitless) }\end{array}$ & Same as i & j \\
\hline & $\begin{array}{l}\text { Proportion of suitable days for } \\
\text { sowing from September 15th to } \\
\text { November } 30 \text { th (fall) (unitless) }\end{array}$ & Same as $\mathrm{i}$ & $\mathbf{k}$ \\
\hline
\end{tabular}

${ }^{*} \mathrm{ET}_{\mathrm{a}}$ refers to actual evapotranspiration calculated from spring C3 crop (spring barley) assuming a soil water-holding capacity of $0.27 \mathrm{~m}$ and a maximum rooting depth of $1.3 \mathrm{~m}$ (more details in the text).

$\mathrm{fET}_{\mathrm{r}}$ refers to the same crop surface as for $\mathrm{ET}_{\mathrm{a}}$ but for reference evapotranspiration; the crop parameters were set according to Allen et al. (1998).

$\ddagger$ Snow cover was estimated using a model validated by Trnka ef al. (2010a, b).

the reference crop surface because it is grown in all the investigated EnZs. When calculating the status of the available soil water, homogenous soil properties were assumed throughout the profile (top and subsoil). The soil water-holding capacity in the top $0.1 \mathrm{~m}$ of soil was assumed to be $0.02 \mathrm{~m}$ and the capacity in the entire profile (a $1.3 \mathrm{~m}$ soil depth) was $0.27 \mathrm{~m}$. Although soil water-holding capacity (as well as other soil parameters) differed across the investigated sites, a uniform soil profile was used to allow station-to-station comparisons. When calculating evapotranspiration, an adjustment for atmospheric $\mathrm{CO}_{2}$ concentration was made using the method proposed by Kruijt et al. (2008) using the $\mathrm{CO}_{2}$ concentrations listed in Table 3.
Creating daily weather series under baseline and climatechange conditions

A restriction on the datasets provided meant that it was not possible to directly apply the observations. Instead, the data were used to train a stochastic weather generator (WG) M\&Rfi (Dubrovský et al., 2004), and a 99-year stochastic daily weather series of global radiation sum, maximum and minimum temperatures, precipitation sum, mean relative air humidity and wind speed were prepared to represent the baseline (1971-2000) climate conditions for each site. In the next step, the baseline WG parameters were perturbed acconting to the climate-change scenarios (Fig. 3) and used as inputs to the AGRICLIM model. 
Table $2 \mathbf{b}$ Overview of the key parameters of each index and threshold values used in the study

\begin{tabular}{|c|c|c|c|c|}
\hline Symbol & Indicator name (units) & Parameter* & \multicolumn{2}{|c|}{ Value $\dagger /$ response (mean $\pm s t d)_{\dagger}^{\dagger}$} \\
\hline a & $\begin{array}{l}\text { Sum of effective global radiation } \\
\left(\mathrm{MJ} \mathrm{m}^{-2} \text { season }^{-1}\right)\end{array}$ & $\begin{array}{l}T_{\text {means }}=5^{\circ} \mathrm{C} \\
\mathrm{ET}_{a} / \mathrm{ET}_{\mathrm{r}}<0.4 \\
\text { Cropף }=\mathrm{sb}\end{array}$ & $\begin{array}{l}6^{\circ} \mathrm{C} /-4 \pm 2 \% \\
0.5 /-24 \pm 11 \% \\
w w /+2 \pm 7 \%\end{array}$ & $\begin{array}{l}4^{\circ} \mathrm{C} / \mathrm{H} \pm 2 \% \\
0.3 /+22 \pm 14 \% \\
g s /-15 \pm 17 \%\end{array}$ \\
\hline $\mathrm{b}$ & Sum of effective growing days (days) & $\begin{array}{l}T_{\text {mean }} \S=5^{\circ} \mathrm{C} \\
\mathrm{ET}_{\mathrm{a}} / \mathrm{ET}_{\mathrm{r}}<0.4 \\
\text { Crop } \| \mathrm{sb}\end{array}$ & $\begin{array}{l}6^{\circ} \mathrm{C} /-15 \pm 8 \text { days } \\
0.5 /-37 \pm 13 \text { days } \\
\text { ww } /+11 \pm 9 \text { days }\end{array}$ & $\begin{array}{l}4^{\circ} \mathrm{C} /+8 \pm 4 \text { days } \\
0.3 /+30 \pm 14 \text { days } \\
\text { gs } /-26 \pm 26 \text { days }\end{array}$ \\
\hline$c$ & Huglin index (unitless) & Effect of latitude & \multicolumn{2}{|c|}{ No effect $/-2 \pm 1 \%$} \\
\hline d & Date of the last frost [date (from January 1st)] & $T_{\min } \|<-0.1^{\circ} \mathrm{C}$ & $+0.5 / 4 \pm 2$ days & $-0.5 /-3 \pm 2$ days \\
\hline $\mathrm{e}$ & $\begin{array}{l}\text { Number of days with water deficits } \\
\text { from April to June (days) }\end{array}$ & $\begin{array}{l}\mathrm{ET}_{\mathrm{a}} / \mathrm{ET}_{\mathrm{r}}<0.4 \\
\text { Crop }=\mathrm{sb}\end{array}$ & $\begin{array}{l}0.5 /-12 \pm 6 \text { days } \\
w w /-6 \pm 13 \text { days }\end{array}$ & $\begin{array}{l}0.3 /+9 \pm 5 \text { days } \\
g s /+2 \pm 14 \text { days }\end{array}$ \\
\hline f & $\begin{array}{l}\text { Number of days with water deficits } \\
\text { from June to August (days) }\end{array}$ & $\begin{array}{l}\mathrm{ET}_{a} / \mathrm{ET}_{\mathrm{r}}<0.4 \\
\text { Crop }=\mathrm{sb}\end{array}$ & $\begin{array}{l}0.5 /-14 \pm 7 \text { days } \\
w w /+5 \pm 7 \text { days }\end{array}$ & $\begin{array}{l}0.3 /+11 \pm 8 \text { days } \\
\text { gs } /+12 \pm 9 \text { days }\end{array}$ \\
\hline $\mathrm{g}$ & $\begin{array}{l}\text { Proportion of suitable days for } \\
\text { harvesting in June (unitless) }\end{array}$ & $\begin{array}{l}\text { SWC range } \\
\quad=0-70 \%\end{array}$ & $\begin{array}{l}0-75 \% / 0 \pm 0 \text { days } \\
5 \mathrm{~mm} /+4 \pm 1 \text { days }\end{array}$ & $\begin{array}{l}0-65 \% / 0 \pm 0 \text { days } \\
\text { No rain } \neq \pm /-4 \pm 1 \text { days }\end{array}$ \\
\hline h & $\begin{array}{l}\text { Proportion of suitable days for } \\
\text { harvesting in July (unitless) }\end{array}$ & Precip $(n) \dagger \dagger=1 \mathrm{~mm}$ & $\begin{array}{l}0-75 \% / 0 \pm 0 \text { days } \\
5 \text { mm } /+3 \pm 1 \text { days }\end{array}$ & $\begin{array}{l}0-65 \% / 0 \pm 0 \text { days } \\
\text { No rain } /-3 \pm 1 \text { days }\end{array}$ \\
\hline i & $\begin{array}{l}\text { Proportion of suitable days for } \\
\text { sowing from March 1st through April 25th } \\
\text { (early spring) (unitless) }\end{array}$ & $\begin{array}{l}\text { SWC range** } \\
\quad=10-70 \% \\
\text { Precip }(n) \dagger+=1 \mathrm{~mm}\end{array}$ & $\begin{array}{l}5-75 \% /-1 \pm 1 \text { days } \\
5 \mathrm{~mm} /+5 \pm 2 \text { days }\end{array}$ & $\begin{array}{l}15-65 \% /-3 \pm 3 \text { days } \\
\text { No rain }+\frac{t}{t}-5 \pm 2 \text { days }\end{array}$ \\
\hline j & $\begin{array}{l}\text { Proportion of suitable days for sowing from } \\
\text { April 26th through May 20th } \\
\text { (late spring) (unitless) }\end{array}$ & & $\begin{array}{l}5-75 \% /-1 \pm 1 \text { days } \\
5 \text { mm/ }+3 \pm 1 \text { days }\end{array}$ & $\begin{array}{l}15-65 \% /-1 \pm 2 \text { days } \\
\text { No rain } /-3 \pm 1 \text { days }\end{array}$ \\
\hline k & $\begin{array}{l}\text { Proportion of suitable days for sowing from } \\
\text { September 15th through November 30th } \\
\text { (early spring) (unitless) }\end{array}$ & & $\begin{array}{l}5-75 \% /-2 \pm 2 \text { days } \\
5 \mathrm{~mm} /+6 \pm 2 \text { days }\end{array}$ & $\begin{array}{l}15-65 \% /-4 \pm 3 \text { days } \\
\text { No rain } /-5 \pm 2 \text { days }\end{array}$ \\
\hline
\end{tabular}

In the right-most column an overview of the effects of modifying the parameter values is given as the mean ( \pm standard deviation) shift of the given indicator across all sites included in the study.

${ }^{*}$ List of parameters of each indicator changed in the sensitjvity runs including their initial values used in the study.

†Value refers to the threshold used in the sensitivity run.

$\ddagger$ The response (mean and standard deviation) refers to the difference between the threshold/assumption used in the study and the changed value indicated before the slash.

$\$ T_{\text {mean }}$ - threshold of daily mean air temperature at $2 \mathrm{~m}$.

"Change in the crop yield affects the calculation of $\mathrm{ET}_{\mathrm{a}}$ and $\mathrm{ET}_{\mathrm{p}}$ where 'sb' refers to spring barley, ' $w w^{\prime}$ to winter wheat and ' $g s^{\prime}$ ' to grassland with a maximum of three cuts per year.

$\| T_{\text {min }}$ - threshold of daily minimum air temperature at $2 \mathrm{~m}$.

* SWC range - the range of soil-moisture content in which soil-tilling operations are considered possible.

t†Precip - threshold of precipitation on the given day.

$\ddagger+$ No rain - daily sum of rainfall $\leq 0.1 \mathrm{~mm}$.

Climate-change scenarios for this study were developed by means of a 'pattern-scaling' technique (Santer et al., 1990) from the outputs of the Global Climate Models (GCMs) and were then used to modify the parameters of the WG (as used in, e.g., Trnka et al, 2004). The 'pattem-scaling' technique defines a climate-change scenario as the product of the standardized scenario and the change in global mean temperature. The standardized scenarios (Fig. 3) relate the responses of climatic characteristics to a $1^{\circ} \mathrm{C}$ rise in global mean temperature $\left(\Delta T_{\mathrm{G}}\right)$. They were detemined by applying a regression method (Dubrovsky ef al., 2005) to the 2000-2099 period, which was obtained from the GCM simulations that had been run with the SRES-A2 (Special Report on Emission Scenarios) emission scenario for the IPCC Fourth Assessment Report (Nakicenovic et al., 2000; Solomon et al., 2007). The projected changes in $\Delta T_{G}$ at 2030 and 2050 were calculated via a simple climate model, MAGICC (Harvey et al., 1997; Hulme et al, 2000), assuming the A2 emission scenario and medium or high climate sensitivity (Table 3). As a 'worst-case scenario' we also assessed changes under a mean global temperature increase of $5^{\circ} \mathrm{C}$. As the role of the climate-sensitivity factor on temperature change by 2050 was relatively small (Table 3 ), the responses of agroclimatic indices were similar and, therefore, we chose to report the results for the higher sensitivity only.

The three GCMs utilized were ECHAM5/MPI-OM (ECHAM), HadCM3 (HadCM) and NCAR-PCM (NCAR). Apart from representing inter-GCM variability quite well (Table 4), 

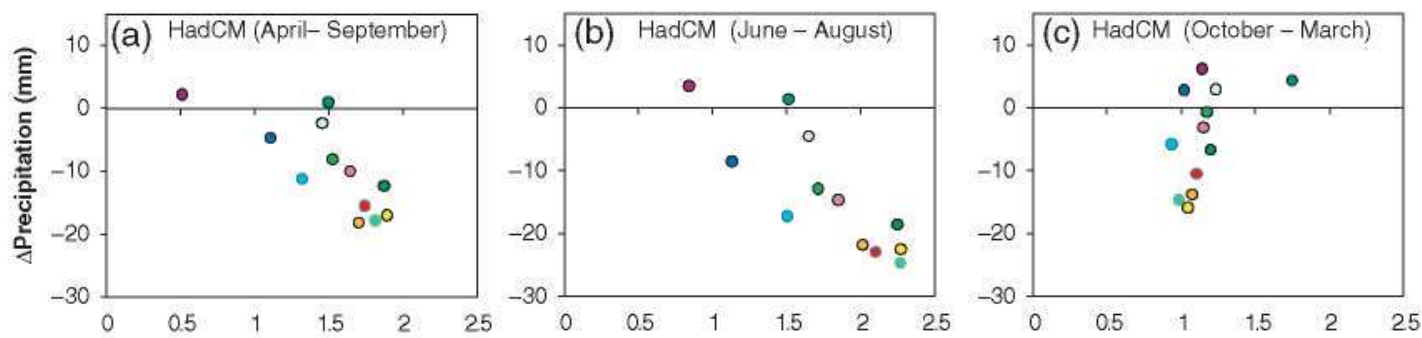

- ALN_zone
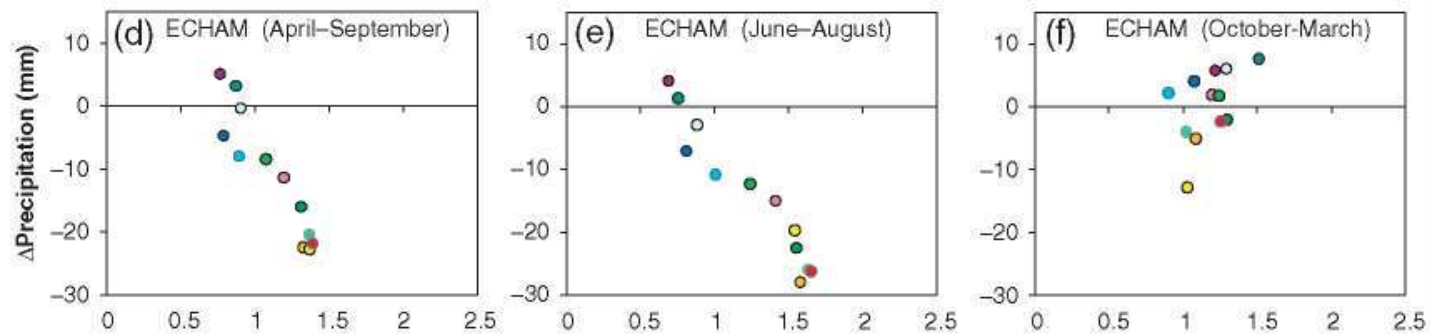

ATN_zone
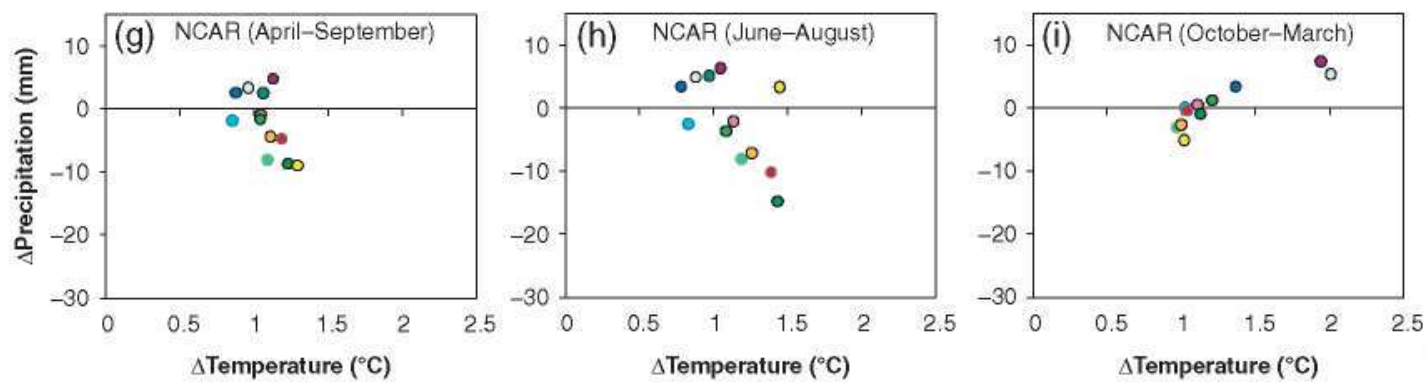

O MDN_zone

O MDS zone

- MDM_zone

Fig. 3 Projected changes in mean temperature and precipitation during different seasons [April-September (a, d, g), June-August (b, e, h) and October-March (c, f, i)] for individual zones as a response to a $1{ }^{\circ} \mathrm{C}$ global warming (compared with 1971-2000). Three GCMs (ECHAM5, HadCM and NCAR-PCM) are presented. The dots represent mean temperature and precipitation changes based on individual stations in their respective EnZs. The product of a $1{ }^{\circ} \mathrm{C}$ warming response and the estimated value of global mean temperature (Table 3) provide absolute values of the changes used to perturb WG parameters.

Table 3 Overview of the scenarios considered in this study, their associated atmospheric $\mathrm{CO}_{2}$ concentrations and global mean temperature values

\begin{tabular}{|c|c|c|c|c|c|}
\hline $\begin{array}{l}\text { Scenario } \\
\text { name }\end{array}$ & $\begin{array}{l}\text { Time } \\
\text { period }\end{array}$ & $\begin{array}{l}\text { Socioeconomic } \\
\text { SRES scenario } \\
\text { driving } \\
\text { GCM runs }\end{array}$ & $\begin{array}{l}\text { Climate } \\
\text { system } \\
\text { sensitivity to } \\
2 \times \mathrm{CO}_{2} \\
\text { concentrations }\end{array}$ & $\begin{array}{l}\text { Scenario } \\
\text { projected } \mathrm{CO}_{2} \\
\text { concentration }(\mathrm{ppm})\end{array}$ & $\begin{array}{l}\text { Scenario estimated } \\
\text { change of } \\
\text { mean global } \\
\text { temperature }\left({ }^{\circ} \mathrm{C}\right)\end{array}$ \\
\hline 2030_med & 2030 & $\mathrm{~A} 2$ & Medium & 451 & $\sim+0.81$ \\
\hline 2030_high & & & High & 458 & $\sim+1.03$ \\
\hline 2050_med & 2050 & & Medium & 533 & $\sim+1.49$ \\
\hline 2050_high & & & High & 536 & $\sim+1.90$ \\
\hline $5^{\circ} \mathrm{C}$ & - & - & - & 900 & +5.00 \\
\hline
\end{tabular}

Medium climate sensitivity indicates that an equilibrium change in global mean surface temperature following a doubling of the atmospheric equivalent $\mathrm{CO}_{2}$ concentration is $3.0^{\circ} \mathrm{C}$, whereas it is $4.5^{\circ} \mathrm{C}$ under high climate sensitivity.

these three GCMs (or previous versions thereof) have been used in a number of impact studies and have generally performed well in reproducing baseline climates in various European regions (e.g. Dubrovský et al., 2005).

\section{Results}

Figures 4-6 and Table 5 present the main results of the study (the EnZ acronyms are defined in Table 1 and 


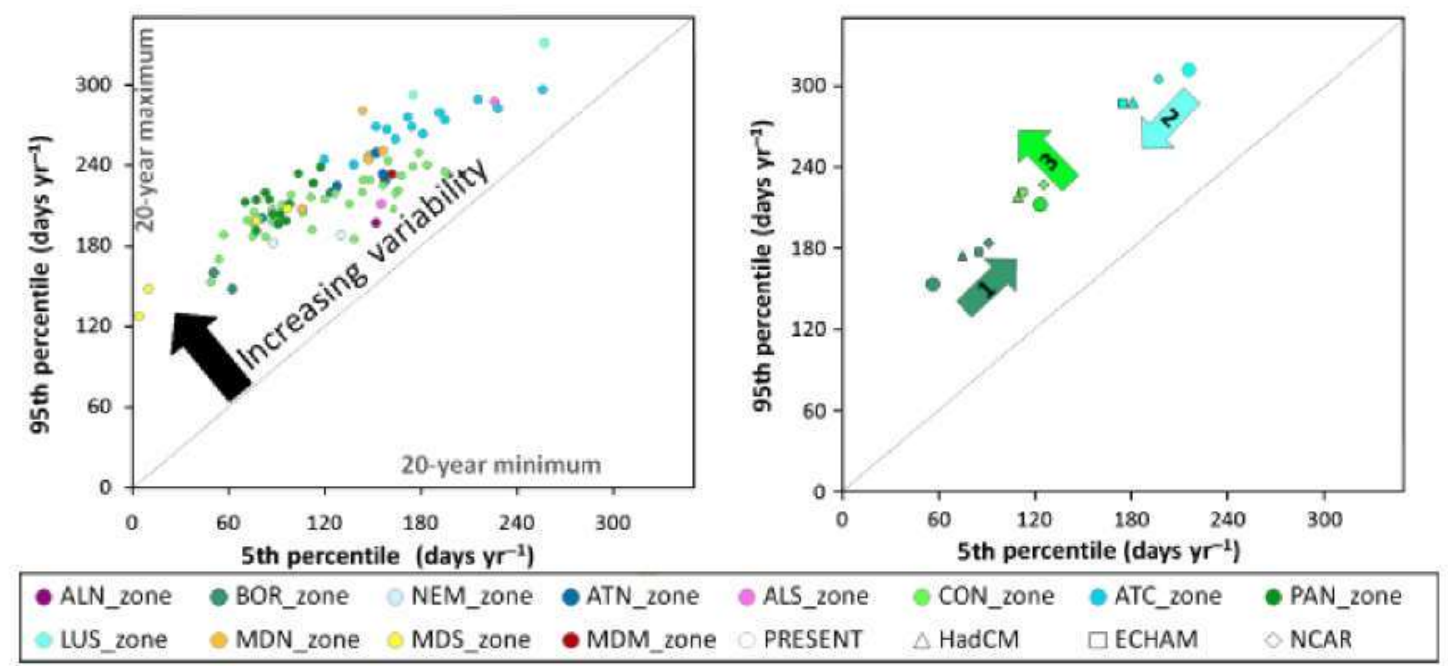

Fig. 4 Aggregation of results from the station to the EnZ level using the duration of the effective growing season (indicator - b) as an example. The left panel shows the calculation of the indicator values for the 95th and 5th percentiles for the 86 sites under the 1971-2000 climate conditions. The right panel illustrates a shift in the mean value of the indicator for the three climate-change scenarios considered and a graphical interpretation of the results. In the BOR zone (1), the indicator increased in both the 20-year minima and maxima, with small changes in the variability. In the LUS zone (2), the indicator decreased in both the 20-year minima and maxima. In the CON zone (3), the indicator increased in the 20-year maximum and showed stagnation or a decrease in terms of the 20-year minimum, which also indicates increased variability.

Fig. 1). Figure 4 explains the process of aggregating the results, Fig. 5 shows the projected changes in individual indicators under different scenarios and Fig. 6 shows the present values for each EnZ as well as estimates according to the SRES-A2 medium climate sensitivity for 2050. Because the study was based on daily data and high-number (99) runs for each site, as well as estimating the central (median) values, changes in the 20-year minima and maxima of the agroclimatic indicators were also assessed to illustrate changes in variability. Aggregations of the site results from the station to the $\mathrm{EnZ}$ level are presented in detail in Fig. 4.

Projected changes in agroclimatic parameters by 2030 and 2050

Figure 3, in combination with Table 4, indicates how overall climatic conditions might change and illustrates change patterns among the seasons and GCMs. More pronounced warming and decreased precipitation between April and September were found for the Mediterranean mountains (MDM), Lusitanian (LUS), Pannonian (PAN), Mediterranean north (MDN) and Mediterranean south (MDS) zones than in the Boreal (BOR) and Alpine north (ALN) zones. The overall patterns of change are consistent for all three GCMs in most zones, except for the colder half of the year. HadCM showed higher changes in temperature and ECHAM more pronounced changes in precipitation, while NCAR showed moderate temperature changes for both in summer, with larger temperature increases in Nemoral (NEM) and ALN during the colder half of the year.

Effective global radiation and effective growing days. During periods of increased drought stress, there was a marked decrease in effective global radiation sums (and thus of potential crop productivity under rainfed conditions) in the MDS, MDN, MDM, PAN and LUS zones (Fig. 5). Increased interannual variability can be seen in the Atlantic north (ATN), Continental (CON) and NEM zones (Fig. 6a and b). An increase of effective global radiation was projected in the BOR, NEM and ALN zones; however, these zones have, in general, less suitable soils and topography. The overall reductions in rainfed production potential, which are expressed in terms of usable global radiation, were quite marked and in line with the changes in the number of effective growing days (Fig. 6b).

Huglin index. Figure 3 shows that temperatures were projected to increase throughout the study region during the period from April to September and, therefore, Huglin indices are also expected to considerably increase across all of the investigated zones (Figs 5a and b, 6c). By 2050, most of the sites in the Alpine south (ALS), MDM, CON and Atlantic 
(a)

\begin{tabular}{|c|c|c|c|c|c|c|c|c|c|c|c|c|c|c|c|c|c|c|c|c|c|c|c|c|}
\hline \multirow[t]{2}{*}{$\begin{array}{c}\text { Environmental } \\
\text { Zone }\end{array}$} & \multicolumn{3}{|c|}{$\begin{array}{l}\text { Effective global } \\
\text { radiation change } \\
(\%)\end{array}$} & \multicolumn{3}{|c|}{$\begin{array}{l}\text { Bffective growing } \\
\text { days change (days) }\end{array}$} & \multicolumn{3}{|c|}{$\begin{array}{c}\text { Huglin index change } \\
(\%)\end{array}$} & \multicolumn{3}{|c|}{$\begin{array}{c}\text { Date of the last } \\
\text { frost change (days) }\end{array}$} & \multicolumn{3}{|c|}{\begin{tabular}{|c|}
$\begin{array}{c}\text { Proportion of dry } \\
\text { days in AMI change } \\
(\%)\end{array}$ \\
\end{tabular}} & \multicolumn{3}{|c|}{$\begin{array}{c}\text { Proportion of dry } \\
\text { days in JA } \\
\text { change (\%) }\end{array}$} & \multicolumn{3}{|c|}{$\begin{array}{l}\text { Proportion of sowing } \\
\text { days - early spring } \\
\text { change (\%) }\end{array}$} & \multicolumn{3}{|c|}{$\begin{array}{l}\text { Proportion of sowing } \\
\text { days-fall change (\%) }\end{array}$} \\
\hline & E & H & $\mathbf{N}$ & E & H & $\mathbf{N}$ & $\mathbf{E}$ & H & $\mathbf{N}$ & $\mathbf{E}$ & $\mathrm{H}$ & $\mathbf{N}$ & $\bar{E}$ & H & $\mathbf{N}$ & E & B & $\mathrm{N}$ & E & H & $\mathbf{N}$ & $\mathbf{E}$ & H & $\mathrm{N}$ \\
\hline ALN & 3 & 6 & 7 & 15 & 16 & 25 & 12 & 16 & 19 & -5 & -6 & -8 & 0 & 0 & 1 & -2 & -2 & -2 & 5 & 7 & 7 & 0 & 2 & 2 \\
\hline NEM & 4 & 5 & 4 & 14 & 9 & 20 & 12 & 22 & 13 & -5 & -5 & -5 & 2 & 1 & 1 & 0 & 4 & -3 & 5 & 5 & 6 & 5 & 6 & 7 \\
\hline ATN & 0 & 0 & 3 & 7 & 3 & 17 & 11 & 15 & 11 & -5 & -7 & -8 & -1 & -1 & -3 & 7 & 11 & 3 & 4 & 3 & 5 & 3 & 3 & 4 \\
\hline ALS & 0 & 1 & 3 & 4 & 2 & 8 & 12 & 16 & 10 & -6 & -9 & -6 & -1 & -2 & -2 & 8 & 9 & 3 & 5 & 5 & 3 & 4 & 4 & 5 \\
\hline PAN & -15 & -11 & -8 & -18 & -13 & -9 & 11 & 15 & 10 & -5 & -6 & -5 & 2 & 2 & 0 & 17 & 16 & 10 & 3 & 3 & 2 & 2 & 3 & 4 \\
\hline LUS & -9 & -9 & -3 & -21 & -21 & -6 & 12 & 16 & 10 & -6 & -7 & -6 & 4 & 5 & 3 & 22 & 23 & 8 & 3 & 2 & 1 & 2 & 2 & 3 \\
\hline MDM & -10 & -7 & -3 & -10 & -7 & -3 & 12 & 15 & 10 & -2 & -3 & -2 & 8 & 3 & 4 & 14 & 13 & 7 & 4 & 3 & 2 & 2 & 2 & 2 \\
\hline MDN & -10 & -7 & -2 & -11 & -5 & -3 & 9 & 12 & 8 & -24 & -23 & -20 & 8 & 6 & 3 & 9 & 7 & 4 & 2 & 1 & 1 & 1 & -1 & 2 \\
\hline MDS & -15 & -14 & -7 & -14 & -10 & -6 & 8 & 12 & 8 & -10 & -11 & -11 & 8 & 8. & 5. & 1 & 1 & 1 & -3 & -2 & -1 & -5 & -3 & 0 \\
\hline
\end{tabular}

(b)

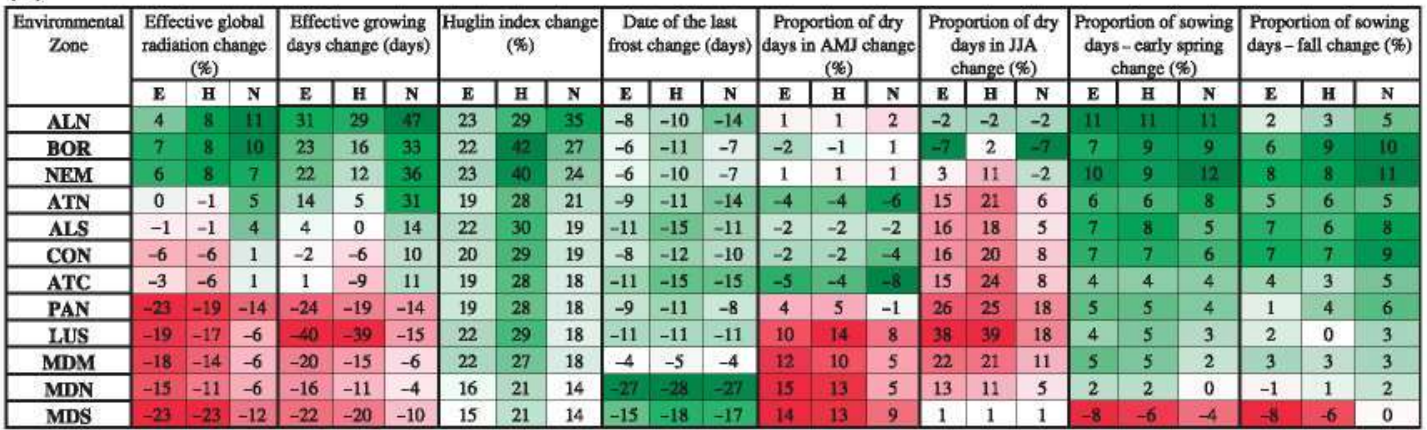

(c)

\begin{tabular}{|c|c|c|c|c|c|c|c|c|c|c|c|c|c|c|c|c|c|c|c|c|c|c|c|c|}
\hline \multirow[t]{2}{*}{$\begin{array}{c}\text { Environmental } \\
\text { Zone }\end{array}$} & \multicolumn{3}{|c|}{$\begin{array}{l}\text { Effective global } \\
\text { radiation change } \\
\text { (\%) }\end{array}$} & \multicolumn{3}{|c|}{$\begin{array}{l}\text { Effective growing } \\
\text { days change (days) }\end{array}$} & \multicolumn{3}{|c|}{$\begin{array}{c}\text { Huglin index change } \\
(\%)\end{array}$} & \multicolumn{3}{|c|}{\begin{tabular}{|c|} 
Date of the last \\
frost change (days)
\end{tabular}} & \multicolumn{3}{|c|}{\begin{tabular}{|c|}
$\begin{array}{c}\text { Proportion of dry } \\
\text { days in AMJ change } \\
(\%)\end{array}$ \\
\end{tabular}} & \multicolumn{3}{|c|}{\begin{tabular}{|c|} 
Proportion of dry \\
days in JA \\
change (\%)
\end{tabular}} & \multicolumn{3}{|c|}{$\begin{array}{l}\text { Proportion of sowing } \\
\text { days - early spring } \\
\text { change (\%) }\end{array}$} & \multicolumn{3}{|c|}{$\begin{array}{l}\text { Proportion of sowing } \\
\text { days - fall change (\%) }\end{array}$} \\
\hline & $\mathbf{E}$ & H & $\mathbf{N}$ & $\bar{E}$ & H & $\mathbf{N}$ & $\overline{\mathbf{E}}$ & H & $\mathbf{N}$ & $\mathbf{E}$ & H & $\mathbf{N}$ & $\bar{E}$ & H & $\overline{\mathbf{N}}$ & $\mathbf{E}$ & H & $\mathbf{N}$ & $\mathbf{E}$ & H & $\mathbf{N}$ & $\mathbf{E}$ & H & $\mathrm{N}$ \\
\hline ALN & 10 & 19 & 28 & 95 & 88 & 129 & 81 & 106 & 126 & -33 & -37 & -40 & -11 & -14 & \begin{tabular}{|l|}
-10 \\
\end{tabular} & -2 & -1 & 2 & 33 & 33 & 38 & 8 & 15 & 17 \\
\hline NEM & 7 & -3 & 16 & 64 & 20 & 117 & 79 & 135 & 83 & -31 & -30 & -33 & -5 & 0 & -10 & 31 & 48 & 5 & 34 & 32 & 36 & 16 & 22 & 26 \\
\hline ATN & -12 & -11 & 7 & 28 & 8 & 80 & 64 & 92 & 71 & -43 & -46 & -52 & -11 & -15 & -23 & 49 & 54 & 14 & 20 & 17 & 24 & 10 & 12 & 11 \\
\hline ALS & -25 & -22 & 5 & -24 & -28 & 18 & 71 & 97 & 61 & -50 & -53 & -50 & 5 & 5 & -7 & 60 & 61 & 20 & 15 & 12 & 5 & 11 & 10 & 18 \\
\hline PAN & -47 & -41 & -28 & -44 & -30 & -25 & 62 & 89 & 58 & -31 & -31 & -27 & 21 & 22 & 4 & 47 & 48 & 37 & 13 & 13 & 10 & -17 & 1 & -2 \\
\hline LUS & -48 & -48 & -27 & -102 & -97 & -64 & 71 & 94 & 57 & -50 & -52 & -50 & 49 & 52 & 34 & 76 & 76 & 48 & 7 & 12 & 5 & -2 & -2 & 5 \\
\hline MDM & -46 & -37 & -18 & -58 & -48 & -17 & 71 & 85 & 58 & -15 & -16 & -13 & 35 & 29 & 9 & 43 & 43 & 29 & 4 & 7 & 5 & -2 & 3 & 11 \\
\hline $\mathrm{MDN}$ & -42 & -34 & -18 & -55 & -38 & -23 & 51 & 68 & 44 & \begin{tabular}{|l|} 
\\
\end{tabular} & -39 & -36 & 45 & 38 & 18 & 17 & 17 & 10 & 2 & 2 & 0 & -9 & -2 & 3 \\
\hline MDS & -57 & -56 & -27 & -62 & -60 & -31 & 48 & 67 & 45 & -54 & -52 & -51 & 27 & 26 & 19 & 1 & 1 & 1 & -27 & -26 & -16 & -37 & -24 & -5 \\
\hline
\end{tabular}

Fig. 5 Changes in the median values of selected agroclimatic indicators relative to the 1971-2000 reference period for: (a) 2030, assuming the SRES-A2 scenario and a medium system climate sensitivity; (b) the same as (a) but for 2050; and (c) for global warming by $5{ }^{\circ} \mathrm{C}$. The color shading represents the positive (green) and negative (red) impacts of these changes and the values represent the medians of all of the sites in a particular zone. The estimates are based on three GCMs, i.e., the ECHAM (E), HadCM (H) and NCAR (N). The proportion of dry days was calculated for April-June (AMJ) and June-August (JJA).

central (ATC) zones will achieve Huglin-index levels that are typical of wine-producing zones.

Date of the last frost. Earlier dates for the last frost were projected in all of the investigated zones (Figs 5 and 6d), although the extent to which these dates changed differed among individual zones. In the ATN, ATC, MDS, ALS and MDN zones, considerably longer frostfree periods were projected, and a larger degree of interannual variability was projected for the ALS and ATC zones.
Number of days with water deficit. The probability of the occurrence of days with water deficit (i.e. an $\mathrm{ET}_{\mathrm{a}} / \mathrm{ET}_{\mathrm{r}}$ ratio $<0.4$ ) from April to June was projected to increase in the LUS, MDM, MDS and MDN zones (Figs 5 and 6e), whereas the most prominent increases in AprilJune drought variability were projected in the LUS and PAN zones. The changes in the June-August droughts were much more uniform in most zones (except ALN and BOR), showing a profound increase in drought duration (Fig. 5) and also variability (in the case of the CON, ATC, LUS, ALS and PAN zones). 
(a)

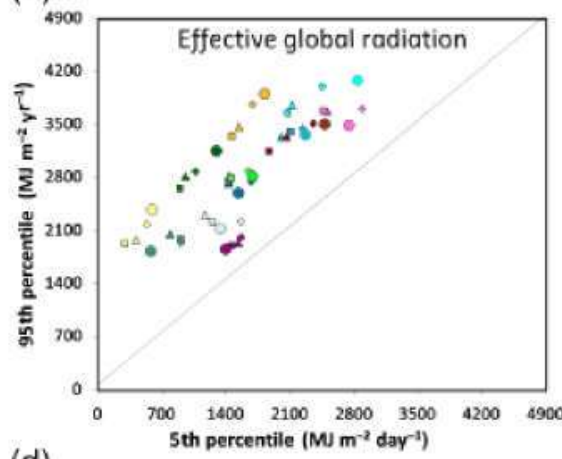

(d)
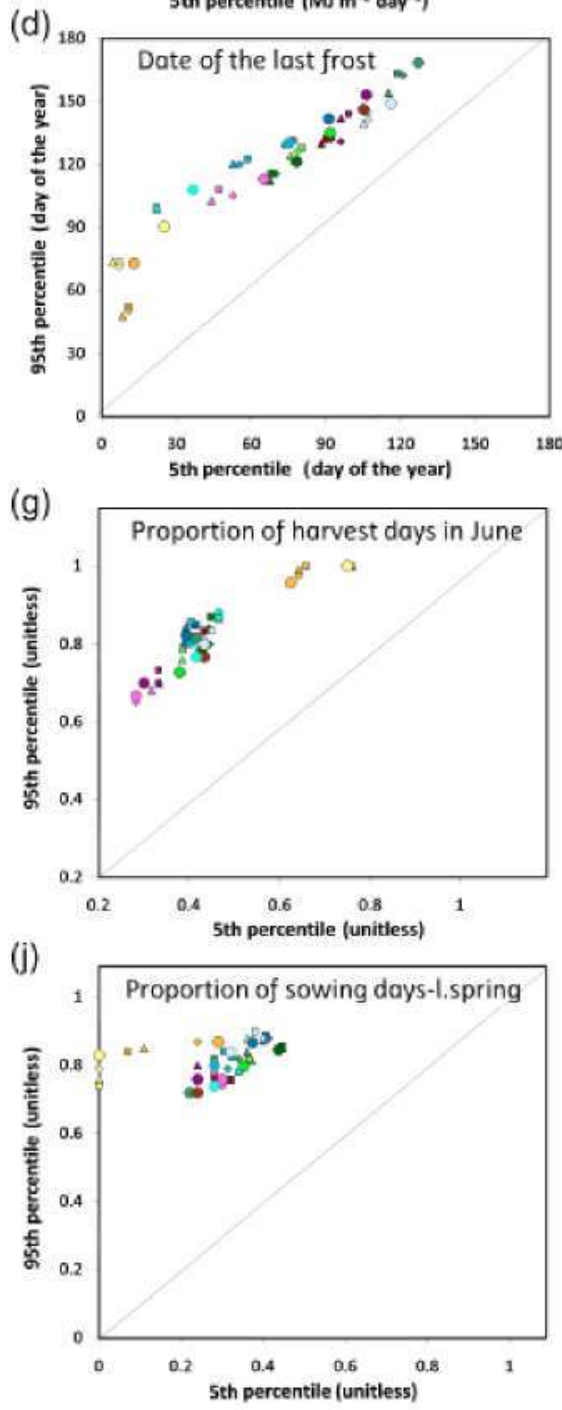

(b)

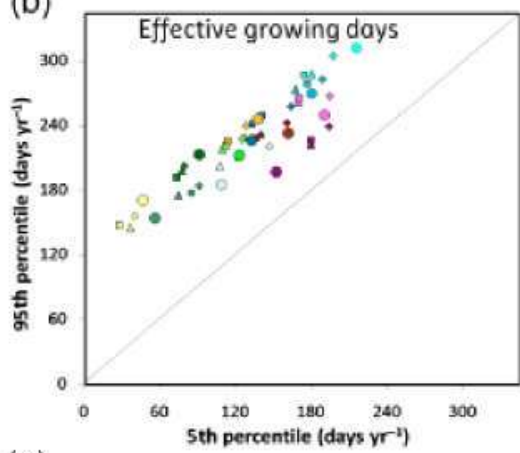

(e)

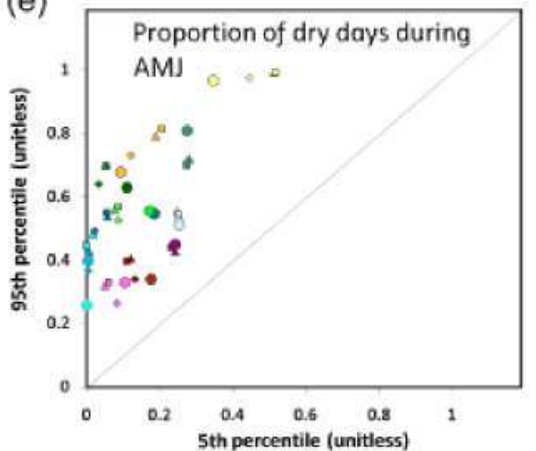

(h)

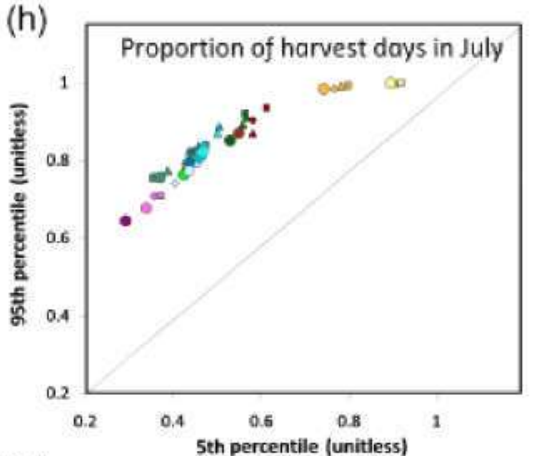

(k)

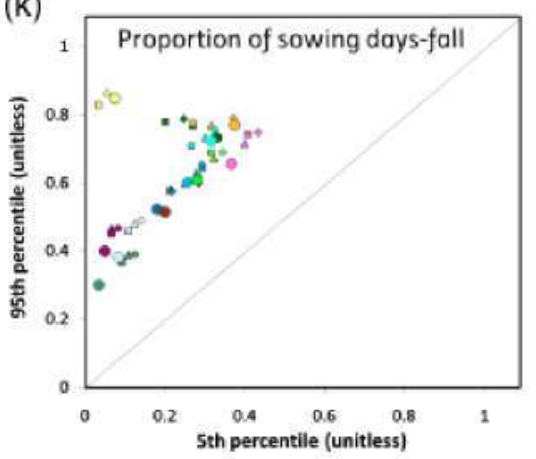

(c)

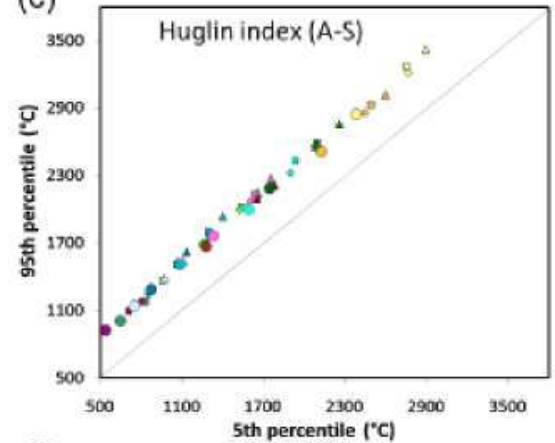

(f)

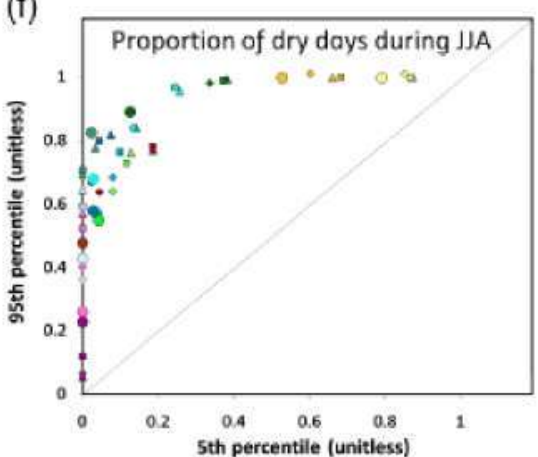

(i)

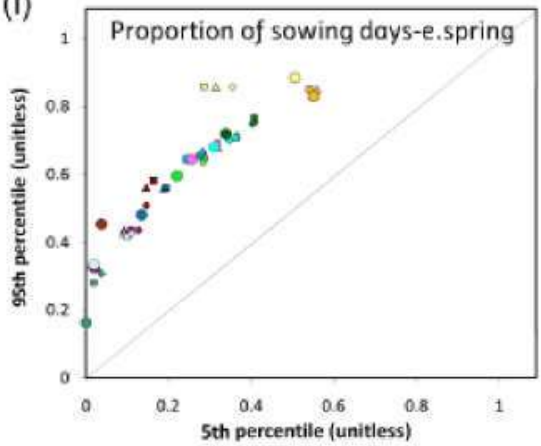

- ALN zone

- BOR_zone

NEM_zone

- ATN_zone

- ALS_zone

- CON_zone

- ATC_zone

- PAN_zone

- LUS_zone

-MDN_zone

MDS_zone

MDM_zone

PRESENT

$\triangle \mathrm{HadCM}$

$\square$ ECHAM

Fig. 6 The values of the (a) effective global radiation, (b) number of effective growing days, (c) Huglin index and (d) frost risk under the present (1971-2000) climate conditions (circles) and those projected assuming a medium climate sensitivity using the A2 emission scenario for 2050. The marks represent the means of the given site indices of each EnZ; (e) the proportion of dry days from April to June and $(\mathrm{f})$ from June to August and the proportion of suitable harvest days in June (g) and July (h); the proportion of suitable sowing days during the early spring (i), late spring (j) and fall (k) sowing windows. The early-spring sowing window is defined as the period from March 1st through April 25th (55 days) and the late-spring sowing window from April 26th through May 20 th ( 25 days). The autumn sowing window ranges from September 15 th through November 30 th ( 76 days) (see legend). 
Table 4 Estimated changes of the mean temperature and precipitation at individual sites averaged over the EnZ for three selected GCMs compared with an ensemble of 14 GCM runs for which SRES-A2 runs were available (see notes for more details)

\begin{tabular}{|c|c|c|c|c|c|c|c|c|c|c|c|c|c|c|c|c|c|c|c|c|c|c|c|c|}
\hline \multirow[b]{3}{*}{ Environmental zone } & \multicolumn{6}{|c|}{$\begin{array}{l}\text { Mean } \Delta \text { of temperature } \\
\text { April-September }\left({ }^{\circ} \mathrm{C}\right)\end{array}$} & \multicolumn{6}{|c|}{$\begin{array}{l}\text { Mean } \Delta \text { of precipitation } \\
\text { April-September }(\%)\end{array}$} & \multicolumn{6}{|c|}{$\begin{array}{l}\text { Mean } \Delta \text { of temperature } \\
\text { October-March }\left({ }^{\circ} \mathrm{C}\right)\end{array}$} & \multicolumn{6}{|c|}{$\begin{array}{l}\text { Mean } \Delta \text { of precipitation } \\
\text { October-March }(\%)\end{array}$} \\
\hline & \multicolumn{3}{|c|}{$\begin{array}{l}\text { Models used } \\
\text { in the study }\end{array}$} & \multicolumn{3}{|c|}{$\begin{array}{l}14 \text { GCM with } \\
\text { SRES-A2 run }\end{array}$} & \multicolumn{3}{|c|}{$\begin{array}{l}\text { Models used in } \\
\text { the study }\end{array}$} & \multicolumn{3}{|c|}{$\begin{array}{l}14 \text { GCM with } \\
\text { SRES-A2 run }\end{array}$} & \multicolumn{3}{|c|}{$\begin{array}{l}\text { Motels used } \\
\text { in the study }\end{array}$} & \multicolumn{3}{|c|}{$\begin{array}{l}14 \mathrm{GCM} \text { with } \\
\text { SRES-A2 run }\end{array}$} & \multicolumn{3}{|c|}{$\begin{array}{l}\text { Models used in } \\
\text { the study }\end{array}$} & \multicolumn{3}{|c|}{$\begin{array}{l}14 \text { GCM with } \\
\text { SRES-A2 run }\end{array}$} \\
\hline & $\mathrm{H}$ & $\mathrm{E}$ & $N$ & Min & $\mathrm{Avg}$ & $\operatorname{Max}$ & $\mathrm{H}$ & E & $\mathrm{N}$ & Min & $\mathrm{Avg}$ & $\operatorname{Max}$ & $\mathrm{H}$ & $\mathrm{E}$ & $\mathrm{N}$ & Min & $\mathrm{Avg}$ & $\operatorname{Max}$ & $\mathrm{H}$ & $\mathrm{E}$ & $\mathrm{N}$ & Min & Avg & $\operatorname{Max}$ \\
\hline ALN & 2.0 & 1.7 & 2.4 & 1.1 & 2.0 & 3.3 & 9 & 10 & 11 & 8 & 11 & 19 & 2.3 & 2.6 & 3.9 & 2.2 & 3.0 & 4.0 & 3 & 14 & 22 & 0 & 16 & 26 \\
\hline BOR & 3.2 & 1.9 & 2.3 & 1.4 & 2.4 & 3.8 & 5 & 10 & 7 & -4 & 8 & 24 & 3.5 & 3.1 & 5.1 & 2.4 & 3.8 & 5.5 & 16 & 14 & 19 & 6 & 16 & 25 \\
\hline NEM & 3.1 & 2.0 & 2.1 & 1.6 & 2.3 & 3.5 & 1 & 2 & 9 & -9 & 5 & 11 & 2.6 & 2.7 & 3.9 & 2.2 & 3.0 & 4.1 & 12 & 12 & 12 & 5 & 13 & 19 \\
\hline ATN & 2.4 & 1.7 & 1.9 & 1.6 & 2.1 & 2.7 & -5 & -6 & 8 & -16 & -1 & 9 & 2.2 & 2.3 & 2.8 & 1.9 & 2.3 & 2.8 & 9 & 7 & 7 & 0 & 10 & 19 \\
\hline ALS & 3.4 & 2.6 & 2.2 & 2.1 & 2.7 & 3.4 & -15 & -15 & 2 & -16 & -8 & 5 & 2.5 & 2.7 & 2.6 & 1.9 & 2.4 & 2.9 & 6 & 8 & -4 & -5 & 2 & 8 \\
\hline $\mathrm{CON}$ & 3.3 & 2.4 & 2.2 & 2.1 & 2.6 & 3.3 & -11 & -11 & 1 & -16 & -7 & 5 & 2.6 & 2.7 & 2.7 & 2.1 & 2.4 & 3.0 & 7 & 4 & -2 & -2 & 3 & 7 \\
\hline ATC & 2.7 & 2.0 & 1.8 & 1.7 & 2.2 & 2.8 & -19 & -12 & -3 & -21 & -11 & 0 & 2.0 & 2.1 & 2.4 & 1.6 & 2.0 & 2.4 & 5 & 5 & 1 & 1 & 4 & 12 \\
\hline PAN & 4.0 & 2.9 & 2.6 & 2.2 & 3.0 & 4.0 & -19 & -22 & -12 & -25 & -14 & -3 & 2.8 & 2.8 & 2.5 & 1.9 & 2.4 & 3.0 & 8 & -1 & -10 & -11 & -2 & 8 \\
\hline LUS & 3.8 & 2.6 & 2.4 & 2.1 & 3.0 & 4.0 & -30 & -27 & -15 & -30 & -21 & -4 & 2.2 & 2.3 & 2.4 & 1.6 & 2.2 & 2.7 & -1 & -6 & -7 & -14 & -5 & 2 \\
\hline MDN & 3.9 & 3.0 & 2.5 & 2.3 & 3.0 & 3.9 & -25 & -27 & -8 & -28 & -16 & -5 & 2.6 & 2.9 & 2.4 & 1.7 & 2.4 & 3.0 & 10 & 5 & -7 & -8 & 1 & 10 \\
\hline MDM & 3.6 & 2.9 & 2.4 & 2.3 & 2.9 & 3.6 & -27 & -30 & -8 & -31 & -19 & -7 & 2.4 & 2.6 & 2.3 & 1.6 & 2.3 & 2.8 & 4 & 1 & -6 & -11 & -2 & 10 \\
\hline MDS & 3.9 & 3.0 & 2.8 & 2.5 & 3.2 & 3.9 & -29 & -39 & -17 & -39 & -22 & -8 & 2.4 & 2.5 & 2.4 & 1.7 & 2.3 & 2.8 & -10 & -17 & -5 & -20 & -12 & -3 \\
\hline
\end{tabular}

Values represent estimates based on the assumption of high climate sensitivity for the target year 2050.

ECHAM (E), HadCM (H) and NCAR (N).

The 14 GCM models used to develop the ranges of GCM projections included BCM2.0 (Bjerknes Centre for Climate Research, Norway), CGMR (Canadian Center for Climate Modeling and Analysis, Canada), CNCM3 (Centre National de Recherches Meteorologiques, France), CSMK3 (Australia's Commonwealth Scientific and Industrial Research Organization, Australia), MPEH5 (Max-Planck-Institute for Meteorology, Gemany), ECHOG (Meteorological Institute University, Bonn, Germany + Meteorological Research Institute, Korea + Model and Data Group at Max-Planck-Institute for Meteorology, Germany), GFCM20 (Geophysical Fluid Dynamics Laboratory, USA), INCM3 (Institute for Numerical Mathematics, Russia), MIMR (National Institute for Environmental Studies, Japan), MRCGCM (Meteorological Research Institute, Japan), PCM and NCCCSM (National Center for Atmospheric Research, USA), HADCM3 and HADGEM (UK Met. Office, UK) and data were downloaded from http://www.mad.zmaw.de/IPCC_DDC/ html/SRES_AR4/index.html 
Table 5 The 5th-, 50th- and 95th-percentile values of the selected agroclimatic indices during the period from 1971 to 2000

\begin{tabular}{|c|c|c|c|c|c|c|c|c|c|c|c|c|c|c|c|c|c|c|c|c|c|c|c|c|}
\hline \multirow[b]{2}{*}{ Environmental zone } & \multicolumn{3}{|c|}{$\begin{array}{l}\text { Effective global } \\
\text { radiation } \\
\left(\mathrm{MJ} \mathrm{m}^{-2} \mathrm{yr}^{-1}\right)\end{array}$} & \multicolumn{3}{|c|}{$\begin{array}{l}\text { Effective } \\
\text { growing days } \\
\text { (days } \mathrm{yr}^{-1} \text { ) }\end{array}$} & \multicolumn{3}{|c|}{$\begin{array}{l}\text { Huglin index } \\
\text { (unitless) }\end{array}$} & \multicolumn{3}{|c|}{$\begin{array}{l}\text { Date of the last } \\
\text { frost (day of the } \\
\text { year) }\end{array}$} & \multicolumn{3}{|c|}{$\begin{array}{l}\text { Proportion of } \\
\text { dry days in AMJ } \\
\text { (\%) }\end{array}$} & \multicolumn{3}{|c|}{$\begin{array}{l}\text { Proportion of } \\
\text { dry days in JJA } \\
\text { (\%) }\end{array}$} & \multicolumn{3}{|c|}{$\begin{array}{l}\text { Proportion of } \\
\text { sowing days - } \\
\text { early spring } \\
\text { (\%) }\end{array}$} & \multicolumn{3}{|c|}{$\begin{array}{l}\text { Proportion of } \\
\text { sowing days - } \\
\text { fall (\%) }\end{array}$} \\
\hline & 5 th & 50 th & 95th & 5 th & 50th & 95th & 5 th & 50 th & 95th & 5 th & 50 th & 95 th & 5 th & 50 th & 95th & 5 th & 50 th & 95th & 5 th & $50^{\text {th }}$ & $95^{\text {th }}$ & $5^{\text {th }}$ & $50^{\text {th }}$ & $95^{\text {th }}$ \\
\hline ALN & 1398 & 1603 & 1855 & 152 & 174 & 197 & 5 & 731 & 932 & 106 & 128 & 153 & 24 & 32 & 45 & 0 & 2 & 23 & 2 & 13 & 33 & 5 & 18 & 40 \\
\hline BOR & 581 & 1417 & 1824 & 57 & 115 & 154 & 650 & 828 & 1014 & 127 & 146 & 169 & 27 & 46 & 81 & 2 & 31 & 83 & 0 & 5 & 16 & 3 & 17 & 30 \\
\hline NEM & 1339 & 1831 & 2127 & 109 & 157 & 185 & 751 & 953 & 1143 & 116 & 132 & 149 & 25 & 37 & 51 & 0 & 7 & 43 & 2 & 14 & 34 & 8 & 20 & 38 \\
\hline ATN & 1536 & 2187 & 2596 & 133 & 190 & 226 & 874 & 1078 & 1293 & 91 & 117 & 142 & 18 & 36 & 55 & 3 & 14 & 58 & 13 & 30 & 48 & 18 & 33 & 53 \\
\hline ALS & 2744 & 3213 & 3486 & 191 & 227 & 250 & 1332 & 1560 & 1770 & 65 & 90 & 113 & 10 & 16 & 33 & 0 & 3 & 26 & 25 & 44 & 65 & 37 & 50 & 66 \\
\hline $\mathrm{CON}$ & 1693 & 2296 & 2812 & 123 & 172 & 212 & 1267 & 1485 & 1691 & 92 & 113 & 135 & 17 & 35 & 55 & 4 & 23 & 55 & 22 & 41 & 60 & 28 & 45 & 61 \\
\hline ATC & 2273 & 2918 & 3360 & 180 & 235 & 270 & 1087 & 1313 & 1512 & 75 & 106 & 130 & 0 & 21 & 40 & 4 & 21 & 57 & 24 & 44 & 65 & 26 & 43 & 60 \\
\hline PAN & 1298 & 2264 & 3143 & 91 & 154 & 213 & 1745 & 1978 & 2191 & 78 & 101 & 121 & 11 & 32 & 63 & 13 & 50 & 89 & 34 & 55 & 72 & 33 & 57 & 73 \\
\hline LUS & 2843 & 3577 & 4079 & 216 & 276 & 312 & 1594 & 1813 & 2000 & 37 & 79 & 108 & 0 & 4 & 26 & 3 & 24 & 68 & 31 & 50 & 68 & 32 & 52 & 73 \\
\hline $\mathrm{MDN}$ & 2161 & 2795 & 3434 & 159 & 201 & 242 & 1585 & 1795 & 1964 & 53 & 61 & 100 & 16 & 30 & 51 & 33 & 51 & 74 & 33 & 50 & 65 & 28 & 51 & 69 \\
\hline MDM & 1811 & 2856 & 4083 & 132 & 191 & 244 & 2207 & 2422 & 2605 & 17 & 48 & 80 & 7 & 37 & 68 & 48 & 83 & 100 & 53 & 68 & 82 & 38 & 58 & 74 \\
\hline MDS & 596 & 1470 & 2371 & 47 & 113 & 171 & 23882 & 2647 & 2852 & 25 & 56 & 91 & 35 & 72 & 97 & 79 & 99 & 100 & 50 & 75 & 89 & 8 & 59 & 85 \\
\hline
\end{tabular}

These values represent the means of the values per given percentile from all of the sites in a given zone. 
Suitability for harvesting. The proportion of suitable harvest days in June (Fig. 6g) was projected to remain high or to increase in the MDN and MDS zones. In the majority of the other zones (e.g. LUS, NEM, MDM and CON), the mean number of suitable harvest days increased together with their variability. In the ALS and ALN zones, the proportion of suitable days in June remained rather low, which is relevant for grassland, forage crops and vegetables grown in these regions. July harvesting conditions (Fig. 6h) were projected to improve in most zones but to worsen for NCAR projections in the BOR and NEM zones.

Suitability for sowing. The number of suitable days for sowing in defined sowing windows was projected to decrease in the MDS and partly in the MDN regions (Figs 5 and $6 i$ and $k$ ). This is due to a considerable decrease in soil-noisture levels, especially in the topsoil, and sowing would still be feasible following irrigation. In the other zones, improved conditions were projected in the case of early-spring sowing (Fig. 6i). Changes in late spring sowing conditions were less consistent, indicating higher interseasonal variability (Fig. 6j). Autumn sowing conditions (Fig, 6k) showed increased variability in the PAN and LUS zones and substantial improvements in the ALN, BOR, NEM, ALS, CON, MDM, ATN and ATC zones.

\section{Agroclimatic conditions under 5 "C warming}

The projected change patterns in Fig. $5 \mathrm{c}$ are similar to those depicted in Fig. 5a and b, although here the changes (especially those that negatively affect the production potential) are more pronounced. In addition to the number of effective growing days, the effective global radiation was projected to decrease for all large agricultural zones investigated in this study except ATN (for the case of changes based on NCAR). Huglin-index values were projected to increase across all zones, reaching unprecedented levels in today's primary wine-growing regions, which may therefore become unsuitable for the currently planted grape varieties. Comparatively, the last frost was projected to occur, on average, much earlier in the year; however, there was also a marked increase in the interannual variability of the last frost date in the ATN, ATC, LUS and $\mathrm{CON}$ zones, which might maintain or even increase frost risk, e.g., for fruit trees, due to a concurrent shift to earlier flowering. The overall drying of most of the agriculturally important zones would be severe (especially during summer), with some zones facing the parallel challenge of higher water deficits and larger interannual variability. Most notable were the changes in water balances in the cases of the LUS and CON zones. There were significant improvements in the number of suitable days for harvest in June and July as well as for early sowing, except for the MDN and MDS zones. The late spring sowing window exhibited a large increase in interannual variability. The sowing of winter crops might become problematic because the proportion of suitable sowing days during autumn will vary dramatically in most zones. The areas that will benefit from a longer and more sustained autumn sowing window are those in the ALN, NEM, BOR and ATN zones.

\section{Discussion}

The environmental stratification of Metzger et al. (2005) and Jongman et al. (2006) clusters areas with similar environmental conditions via the use of a limited number of variables that may not sufficiently capture the large diversity of agroclimatic conditions across Europe. The values of the agroclimatic indices obtained from the stations in the southern zones (MDS and MDN in particular) were more internally consistent than those obtained from stations in other zones (Fig. 4a). There was also a pronounced difference in the behavior of sites in zones with large oceanic influences (ATN, ATC or LUS) compared with the continental climate of sites in the PAN zone. The largest internal variability was seen within the CON zone, which has the largest number (12) of strata (Metzger et al., 2005); however, the stratification used provides the most detailed classification available based on climatic data from recent decades. Moreover, several studies have demonstrated a close relationship between the EnS (Ewert et al., 2005; Smit et al., 2008) or corresponding regions (Reidsma, 2007; Reidsma et al, 2009) and the productivity of agricultural crops (e.g. maize, winter wheat or grassland).

We are aware that environmental conditions represent a continuum across space and time and that any attempt to stratify them inevitably leads to simplifications, which in turn may result in similar values for particular agroclimatic indicators across several zones. In fact, Metzger et al. (2005) reported that the first map of the EnS included dispersed scatter for small regions of only a few square kilometers and, therefore, all regions smaller than $250 \mathrm{~km}^{2}$ were assigned to the strata of the neighboring grid cells. Despite these possible shortcomings, we view the clustering of sites in climate-change impact studies based on $\mathrm{En} Z$ as a valuable complement to classifications based on administrative regions (e.g. Olesen \& Bindi, 2002; Reidsma et al., 2009) or other ad hoc classifications (e.g. Christensen \& Christensen, 2007). 
The ALN zone was represented by a single weather station, which is located in the largest agricultural area within the region. While the variation in the ALN agroclimatic conditions is large (Skjelvăg, 1998), this single site adequately represents the northernmost fringe of European agricultural production. The ALN zone may expect the greatest increase in the number of effective growing days; by 2050 , the increase may match the present agroclimatic conditions of the ALS (Fig. 6b). Because of the high latitude of the ALN zone, the relative increase in the effective global radiation will be negligible. Overall, the agricultural potential of this zone is likely to improve; however, this is marginal in a European context due to the relatively small acreage of agricultural land in the zone (Table 1).

\section{$B O R$}

The growing conditions of the BOR region include special features that constrain yield formation (Peltonen-Sainio et al., 2009b). The number of effective growing days under the present climate conditions is strikingly low (Table 5, Fig. 6a); the short growing season is further hampered by a relatively high risk of early-summer night frosts and a high proportion of dry days. Therefore, yields are typically far lower in the BOR zone than in other European regions (Peltonen-Sainio et al, 2009a). Presently, only the late-spring sowing window is used, and most sowing occurs even beyond late spring. This is due to saturated soils that need to dry before sowing is possible with heavy machinery (Fig. 6j), low temperatures that slow germination, seedling establishment and early growth and a greater propensity for night frosts, which make early sowing economically risky (PeltonenSainio et al., 2011). The overall low numbers of suitable days during the autumn sowing windows in the ALN, $B O R$ and NEM zones are caused by ample precipitation and/or the early start of the winter season. The BOR zone has the lowest number of such days in late autumn (Table 5) and thus the present sowing window ranges from mid-August to mid-September (Peltonen-Sainio et al., $2009 \mathrm{~b})$. Compared with the ALN zone, the increase in the number of effective growing days was projected to be much smaller as a consequence of the projected increase in the proportion of dry days in the BOR zone. Earlysummer drought already severely limits yields in some years (Peltonen-Sainio et al., 2009b; Rötter et al., 2009). Of all the investigated zones, the MDS, PAN and BOR zones will have the fewest number of effective growing days by 2050 (Fig. 6a and b). It is likely that the agricultural potential of the BOR zone will remain comparatively low, even in the scenario of a $5{ }^{\circ} \mathrm{C}$ climate change.
Despite the fact that the NEM sites represent the upper limit of the NEM region, the accumulated sum of global radiation is quite similar across the entire NEM region (Skjelvagg, 1998). The low yields in this region are usually attributed to exceptional conditions that cause late maturity and/or pest infestations rather than low radiation input. The fraction of dry days varies across the region, which causes some variation in the suitability of both spring and autumn for sowing. The selected range of indices did not include winter temperature, which is known to be an important yield predictor for perennial and autumn-sown crops in the NEM, BOR and ALN areas (e.g. Samnordisk planteforedling, 1992; Blombäck et al., 2009). Climate changes in the NEM region are likely to increase the crop-yield potential through improvements in the effective global radiation, effective number of growing days, date of last frost and proportions of sowing days (Fig. 6). Only the projected increases in the number of dry days during summer and interseasonal variability could potentially counteract the increases in crop-yield potential. Previous climate-change assessments for grass leys in Sweden have projected a considerably increased production in spring due to increased temperature, which enables an increased use of the high-intensity solar radiation in the spring (Torssell et al., 2008). Using the present climate analogy, the NEM zone would achieve growing conditions that are close to those of present-day ALS, with a frequency of drought days and sowing conditions that are similar to those of the present-day ATN zone. These changes would probably support a shift from springsown to autumn-sown cereals (Eckersten et al., 2008) and would enable the expansion of the cultivation of forage maize and similar crops. Under the $+5^{\circ} \mathrm{C}$ scenario, the NEM area would achieve a Huglin index that is comparable to that observed in the present-day MDM area; the water deficit during dry years (based on a 20-year-return probability) would increase substantially.

\section{ATN}

The high yield potential of the north-western ATN zone, which is indicated by the relatively large effective global radiation in these areas, is confirmed by yield statistics for winter cereals (e.g. Schaller \& Weigel, 2007). In terms of grassland productivity, Smit et al. (2008) claimed that the ATN zone has the highest production potential among all of the evaluated zones, followed by the ATC and LUS zones. This high productivity results from the relatively long summer days in combination with sufficient precipitation during the 
growing season, a long grain-filling phase due to moderate summer temperatures and recent increases in the thermal growing season (Chmielewski et al, 2008). The high productivity is particularly evident in fruit-growing regions, e.g., near the Ellbe estuary (Henniges ot al., 2007). Because of phenological shifts due to recent warning, resulting in earlier bud break and flowering, the risk for frost damage has remained unchanged for grapevines and fruits (Rochette et al., 2004; Stock et al., 2005; Chmielewski et al., 2008; Henniges et al., 2007; Eitzinger et al., 2009) and it is likely to remain unchanged under the projected climate change. Increasing winter and summer temperatures may cause yield reductions in winter cereals (Kristensen et al., 2011), but increasing summer drought may not necessarily reduce yields in this zone, where winter cereals develop deep roots and where current rainfall is generally not limiting. The increasing number of dry days in the June-August period (Fig. 6f) may reduce the yields of spring cereals (Wechsung et al., 2008); however, this phenomenon might be partly compensated for by the earlier sowing of spring cereals (Olesen, 2005). Climatechange studies have generally shown an expansion of warn-season crops (e.g. maize, sunflower, soybean and grapevine) in this zone under climate change (Fronzek \& Carter, 2007; Olesen et al., 2007). This was confirmed by the projected changes in growing days, the Huglin index and date of last frost (Fig. 5).

\section{ALS}

Mountain chains act as climatic borders for the surrounding regions (e.g. delineating northern from southern EnZs in the Alpine mountain range) and contain a variety of climatic conditions due to strong topographical effects. This must be considered for the mountain regions in the ALS zone (e.g. the Alps and the Massif Central), resulting in a high spatial variability of climates. While there were only two stations selected in the ALS zone, they represent two of the six strata, wherein almost three-quarters of the agricultural area of the zone are located. It should be stressed that these stations represent low elevations that are relatively suitable for crop production. The potential productivities of both sites are at the higher end of all of the analyzed sites (Fig. 6) and the frequency of drought is very low, even during the summer montlus (Fig. Ge and f). The effect of clinate change here was neutral to slightly positive, indicating slight increases in the variability and mean sum of effective radiation (Fig. 6a) and in the mean duration of effective growing days. The Huglin index of this region suggests that it might become suitable for grapevine cultivation; however, additional constraints in the ALS region, such as very low winter temperatures, poor soils and inaccessible terrain, will limit the cultivation of grapevines and other crops. There was a marked increase in projected days with water limitation (Fig, 5) during summer and in summer drought variability (Fig. 6f), threatening the productivity of permanent grasslands, which is one of the largest concerns in the eastern and southern parts of the Alps (Eitzinger et al., 2009). Specifically, a mean global temperature increase of $5{ }^{\circ} \mathrm{C}$ would lead to a partial deterioration of productivity (Fig. 5). In the more humid ALS regions (north), an increased grassland biomass production potential can be expected. Similar effects have been projected for arable crop production in recent studies (e.g. Eitzinger et al., 2009), with increasing crop-yield potential via the introduction of higher-yielding and later-ripening cultivars (e.g. maize) or new crops (e.g. soybeans and sunflower).

\section{CON}

The CON zone is the EnZ with the largest number of strata (12), the largest acreage of agricultural land (Table 1) and a high degree of variability between sites. The comparable potential productivity of the CON zone (expressed as effective global radiation and growing days) agrees well with the grassland productivity estimated by Smit et al. (2008). For the projected climate change, the overall mean for all CON sites (Figs 5 and 6 ) suggests no change, or even a decrease, in the effective global radiation sum and number of effective growing days. Whereas sites north of the Alps mostly showed increases in both indicators (see also Trnka et al., 2010a), those in the southern parts of the CON zone demonstrated decreases of both indicators as a consequence of increased water stress. The projected values of the Huglin index suggest that viticulture will require changes in the cultivars grown (e.g. Stock at al., 2005; Eitzinger et al., 2009). The mean proportion of dry days from April to June did not change appreciably on average (Fig. 6e and f); however, there was a pronounced south-to-north gradient, with sharp increases in the proportion of dry days at southerly sites. The increase in the number of dry days from June to August represents a risk for rainfed agriculture across the present CON area, and this has already partly been reflected in the observed trends of drought since the 1940s-1950s (e.g. Dai et al, 2004; van der Schrier et al., 2006) as well as in national and regional studies (e.g. Wechsung et al., 2008; Dubrovský et al., 2009). Recent studies (e.g. Jacobeit et al., 2009; Trnka et al., 2009) have also pointed to the fact that changing frequencies of temperature and precipitation extremes are associated with changes in the frequency of particular circulation types. The early-spring sowing window should become 
longer (on average) and more stable (Figs 5 and $6 i$ and k). These changes agree well with the shorter duration of snow cover, increasing spring temperatures and earlier start of the spring season (e.g. Chmielewski et al., 2005; Brázdil et al, 2009). Harvesting conditions in June (when the harvest of some crops will take place in the future) are not favorable, making the planning of suitable harvest times more challenging.

\section{PAN}

The climate of the PAN zone can be viewed as a variation of the continental climate (CON). The PAN zone primarily consists of flat regions and has warmer and drier summers and higher mean wind speeds compared with the neighboring CON region (e.g. Auer, 2004; Auer \& Korus, 2005). This leads to typical steppelike conditions and high reference evapotranspiration rates during summer (Müller, 1993). Agricultural production in the PAN region under the present climate is primarily restricted by a lack of water, particularly during summer (Table 5). The PAN region was projected to have the sharpest declines in effective global radiation as a consequence of large decreases in water availability (Figs 5 and 6a). The projected trend toward a warmer and drier climate is more pronounced here than in other zones (Fig. 3), and the severe consequences of climatic variability in parts of the PAN zone have been highlighted elsewhere (e.g. Seneviratne th al, 2006). Crop production in the PAN is, to a large degree, dominated by arable production (especially that of maize, sunflower, winter wheat and spring durum wheat) and the results of crop-model-based studies in some countries have shown significant shortening of the growing season and a reduction in crop yields from increases in the frequency of summer drought and heat waves (Alexandrov \& Hoogenboom, 2000). This shortening of the growing season could cause a significant loss in crop production and revenue in regions where no additional water sources are available (Eitzinger et al., 2003; Alexandrov \& Eitzinger, 2005). The PAN zone is also renowned for viticulture and high-quality white wines; however, the Huglin index in this region in 2050 is projected to become comparable to that of the present MDN zone.

\section{ATC}

The present agroclimatic conditions in the ATC zone result from its proximity to the sea, which reduces interseasonal variation in comparison to other zones; however, variability among stations at different altitudes and among seasons is still considerable, particularly for those indices that are associated with soil- moisture content. This can be explained by spatiotemporal differences in rainfall, wherein the oscillatory component in the rainfall series plays a key role (e.g. De Jongh et al., 2006; Ntegeka \& Willems, 2008). Frequent high-precipitation events during the late-spring sowing window are the primary cause of the lower number of suitable sowing days. The high number of effective growing days (Table 5 and Fig. 6b) and, to some extent, the effective global radiation levels (Fig. 6a) result in high yields of key field crops here compared with other European regions (e.g. Olesen et al., 2011). The Huglin index of this region suggests only a marginal suitability for wine growing (e.g. Robinson, 2006); however, at some ATC sites, the conditions have been improving over the past few decades, as documented by Schultz (2000) and Eitzinger et al. (2009). The effective global radiation is not expected to change significantly, while the number of dry days is likely to increase (Fig. 6). Whereas Stock et al. (2005) demonstrated the tendency of a northward viticultural shift and an ascent to higher elevations, Schultz et al. (2005) have calculated a similar rate of increase in the Huglin index for Geisenheim/Rheingau (ATC-ATN) as found in our study. For the SRES-A1B scenario, projections have shown average shifts of the latest frost to earlier dates by 28 days for the period of 2071-2100 in Germany (Chmielewski et al, 2008). The earlier start of the growing season results in a higher proportion of suitable sowing days in spring, as was also found by Rötter \& van Diepen (1994). The tendency toward more drought stress (Figs 5 and $6 e$ and f) was also reported by Gupta et al. (2006) for the Netherlands and by Holden et al. (2008) for Ireland.

\section{LUS}

Despite having the smallest total area of the zones considered in this study, the LUS zone has one of the largest proportions of agricultural land among all of the investigated zones. The large sum of effective global radiation and large number of effective growing days suggest a high potential productivity (Table 5), which is reflected in crop yields (Reidsma, 2007) and agrees with the findings of Smit et al. (2008) and Fisher et al. (2002) for grassland productivity. This region also contains well-known wine-producing regions, which have historically focused on the production of high-quality wines corresponding with favorable Huglin-index values (Fig. 6c). The risk of late frosts is low (Fig. Gd), as are the risks of drought occurrences during the early growing season and in the summer months, and there is a high proportion of days suitable for harvesting and sowing. The agroclimatic conditions of the LUS zone could potentially worsen through decreases in effective 
global radiation sums and effective growing days. Despite these changes, the levels of the last two indicators will remain comparatively high in the LUS region, accompanied by low drought risk in the early growing season. The change in the frequency of summer drought stress is quite important, as it will reach levels that are presently seen at PAN sites. The proportion of suitable harvest (Fig. $6 \mathrm{~g}$ and h) and early sowing days (Fig. 6i) will improve, while the conditions during the latespring and fall sowing windows will not change. Because the LUS zone hosts key wine-producing regions, an increase in the Huglin index (Fig. 6c) to levels near those presently observed in the MDN zone poses questions about the future of current terroirs (Seguin \& Garcia de Cortazar, 2005).

\section{$M D M$}

Although only represented by one station in this study, the analysis of these results offers interesting information regarding potential impacts. Overall, the MDM zone is quite similar to the MDN zone (discussed below). Interestingly, the index that measures the change in last frost did not follow the pattern of MDN and MDS, as it retains the relatively large variability observed in the 1971-2000 period. The proportion of dry days for the period from April to June and June to August is expected to increase considerably for the MDM zone, as also predicted by Iglesias at al. (in press-a).

\section{$M D N$}

The results for the MDN zone reported herein are primarily based on sites in the Central Mediterranean and the Iberian Peninsula (Fig. 1). The current agroclimatic conditions at the analyzed sites suggest high potential productivity (Table 5), which is reflected in the very high grain maize and winter wheat yields in the MDN zone (Iglesias \& Quiroga, 2007; Reidsma, 2007; Reidsma et al., 2009; Iglesias et al., in press-a) and in the high values of grassland productivity that have been estimated by various approaches (Fisher et al., 2002; Smit et al., 2008). However, grassland yields based on national statistics (Smit et al., 2008) show that the MDN zone has a significantly lower productivity than the PAN and MDM zones, which may reflect frequent summer droughts (Fig. 6f) in combination with a lack of grassland irrigation (in contrast to arable crops). Harvest (Fig. $6 \mathrm{~g}$ and $\mathrm{h}$ ) as well as sowing suitability during early spring and fall were projected to reach very high levels. The late-spring sowing window will become unreliable as a result of spring droughts, which will make sowing or any other tilling operations problematic. Climate change is projected to decrease the sum of effective global radiation and increase the proportion of dry days during the early growing season together with an increase in interseasonal variability. An analysis of the 1955-2007 rainfall series confirms the current trend of reduced rainfall during spring and winter (Bartolini et al., 2008). As a consequence, the proportion of drought days during summer (Fig. 6f) will vary less because almost all years will be affected by severe drought. Aside from drought, one of the perceived threats of climate change is the increasing probability of encountering lethal temperatures close to $40^{\circ} \mathrm{C}$. Crop-survival thresholds are still poorly understood and, thereby, there is a serious risk of future heat-wave-induced crop damage (e.g. Battisti \& Naylor, 2009). Consequently, a significant increase in water demand for irrigation can be expected for this and the MDS region, not only for summer crops but also for winter crops, where in some regions the additional demand might not be met by the available water resources (Simota, 2009). The projected increase in temperature and decrease in precipitation in the MDN zone will also significantly decrease the soil-water content and water runoff to the Adriatic coast, resulting in negative consequences for the vegetation and agricultural production therein (Vučetić \& Vučetić, 2000). The higher proportion of dry days during the period from April to June indicates a likely earlier onset of the wildfire season and an increased fire risk during summer (Vučetić et al., 2006) as a consequence of longer summer dry spells (Vučetić, 1998). The impact of climate change on wine quality will be very high, as shown by Huglin indices (Fig. 6c) of around 3000, which are indices that are typically associated with the production of dessert wines (Grifoni et al., 2006). An increasing temperature will reduce the occurrence of frost, but the real effect will have to be evaluated by considering the earlier onset of phenological phases and also the possible modification of air circulation (e.g, the possible intrusion of cold air from eastern Europe during March and April).

\section{MDS}

The potential rainfed productivity (Table 5) of this zone is limited by drought (Fig, 6e and f), not only during summer (Fig. 6f) but also in spring (Fig. 6e) and autumn, although this could be alleviated by irrigation (Reidsma et al., 2009). A low productivity here was also reported by Smit et al. (2008) for grasslands and for winter wheat and maize by Reidsma (2007) and Reidsma et al. (2009). In terms of harvest suitability (Fig. $6 \mathrm{~g}$ and $\mathrm{h}$ ), June and July exhibited the most favorable conditions of all of the investigated zones; 
however, the durations of the sowing windows (in particular those during early spring and autumn) were particularly low and variable (Fig. 6i and k), mostly as a consequence of increasingly dry soil conditions. Climate-change projections indicated decreases in potential productivity due to increases in the proportion of dry days and a decrease in the interannual variability of these parameters; however, this is hardly surprising given the character of the climate changes in these regions (Fig. 3). More specifically, sharp reductions in precipitation during summer and also in winter months (e.g. Zanis et al., 2009) will likely result in increases in the number of consecutive dry days and heat-wave frequency (Beniston et al., 2007) and the consequent decrease of soil-water content (Calanca et al., 2006). Similarly to the MDN zone, the variability in the proportion of drought days during both evaluated windows (Fig. 6e and f) will decrease during summer and spring, which will further increase the risk of forest fires in the MDS region (Lavalle et al., 2009). The likely impact of climate change on wine quality in the MDS zone is thought to be significant and negative (Fig. 6c). Finally, as in the MDN region, more effective irrigation methods, water management and policy in this region will be the main determinants of future crop distribution and productivity (Iglesias et al., 2007, in press-b; Iglesias 2009; Katerji et al., 2010).

\section{Uncertainties in projected impacts}

To date, the existing projections of European crop yields under climate change have been based mainly on the outputs of crop-growth models. While this strategy can be used to estimate the impact of climate change on crop yield, the simulation models usually do not capture crop management or environmental factors (e.g. extreme weather events) in their entirety. Moreover, crop-simulation studies are often linited with respect to the number of crops covered or the spatial coverage. The present study, which is based on selected indices, provides general, although limited, conceptions about fundamental agroclimatic conditions that govern cropyield potentials and conditions for crop management across Europe. All assumptions and thresholds used in the study were based on published literature, and the sensitivity of our conclusions to the assumptions made was scrutinized by a sensitivity analysis (Table $2 b$ ), which showed that changing the thresholds used (e.g. $\mathrm{ET}_{\mathrm{a}} / \mathrm{ET}_{\mathrm{r}}$ ratio) or modifying assumptions made (e.g. applying different reference surfaces for ET calculations) inevitably leads to variations in the absolute values of the indicators. However, the overall impact of the modified thresholds on the study conclusions was limited, i.e., the relative differences between the baseline conditions and those expected by 2030 and 2050 remained qualitatively the same.

Throughout most of the investigated zones, there were signs of deteriorating agroclimatic conditions and a need for adaptive measures to either increase soilwater availability (e.g. by irrigation or crop-management options) or crop drought resistance in the majority of the zones. While the impacts were demonstrated only for a selection of three GCMs, they represent a wide range of future projections quite well (Table 4).

\section{Perspectives on European agriculture under climate change}

Earlier European studies have emphasized that agriculture is expected to potentially benefit from climate change (e.g. Rötter \& van Diepen, 1994; Olesen \& Bindi, 2002); however, the responses of agricultural systems to changes in the frequency and severity of climatic extremes have rarely been considered in earlier assessments. Recent examples of damage in relation to floods, drought, hail and storms have revealed that the impacts of such extreme events are large (Kabat et al., 2005; Gupta et al., 2006). The present study confirms the substantial northward expansion of the thermal suitability of crop production in Europe under climate change found previously, e.g., by Fisher et al. (2002) and Olesen et al. (2007). The areas where conditions for rainfed crop production will be improved are restricted to the Northern regions (ALN, BOR and NEM), and partly in the ATN and the Alpine Mountains (ALS). This is the result of drier summers in much of central and southern Europe that will limit crop growth during summer unless irrigation is applied. This is not fully consistent with the results of Fischer et al. (2005), who predicted negative impacts on crop productivity only for Western Europe. The projected climate change does not seem to severely interfere with the possibilities for sowing and, to a lesser extent, harvesting, thus generally offering possibilities to adapt by changing sowing and harvesting dates in most European regions. The analysis shows that if the climate patterns evolve according to the assumptions and scenarios we used, some of the currently highly productive agricultural regions in Europe may be at risk of reductions in suitability for rainfed crop production. This is particularly the case for Western France and also parts of South-Eastern Europe (Hungary, Bulgaria, Romania, Serbia, etc.), where summers will become considerably hotter and drier, reducing crop yields and increasing yield variability. In these regions, winters will still be too cold to allow crop growth during winter. The Mediterranean zones will suffer from increases in dryness during spring and sharp declines in rainfed crop- 
production potential, posing the challenge of added irrigation capacity to irrigated Mediterranean areas, which must therefore become more efficient (Playan \& Mateos, 2005). As shown by the Huglin-index values, the conditions for traditional crops such as grapevines will become more challenging, as also found by Jones et al. (2005) and Olesen et al. (2011).

\section{Conclusions}

Based on the evidence provided by our study, it can be concluded that rainfed agriculture in Europe may face higher climate-related risks; however, the analyzed agroclimatic indicators will likely remain at levels that permit acceptable yields in most years. Concurrently, our findings also suggest that the risk of extremely unfavorable years, resulting in poor economic returns, is likely to increase in many European zones. This projected increase in the variability of climatic suitability for crop production is particularly challenging for crop management and for agricultural policy, which aims to ensure stable food production and viable conditions for farmers. This therefore suggests that agricultural policy should encourage the adoption of both agroecological techniques and a diversification of production to increase crop resilience to climatic variability as well as the implementation of various insurance schemes (e.g. strategic grain stocks, farmer drought and flood insurances) and improvements in the efficiency of agricultural water use.

Because the costs of timely action may far outweigh the costs of inaction, an analysis of agrometeorological conditions in combination with agroclimatic projections under different climate-change scenarios across Europe offers the possibility of supporting early decision-making with regard to opportunities and risks. The analysis presented here should be conducted at regional and local levels to better reflect how specific localities may be affected.

\section{Acknowledgements}

This study was supported by the following projects: COST 734 (CLIVAGRI); DFFE 3304-FVFP-60651; Research plan No. MSM6215648905; KONTAKT OC187 and CzechGlobe - Centre for Global Climate Change Impacts Studies, Reg. No. CZ.1.05/ $1.1 .00 / 02.0073$.

\section{References}

Alcamo J, Moreno JM, Nováky B at at. (2007) Europe. Climate change 2007: impacts, adaptation and vulnerability. In: Contritution of Wonking Group II to the Fourth Assessment Report of the Intergezersmsental Panel ous Climatz Chaspe (eds Parry ML, Canziani OF, Palutikof JP, van Jer Linden PJ, Hanson CE), PP. 541-580. Cambridge University Press, Cambridge, UK.
Alexandrov A, Hoogenboom $G(3000)$ The impact of climate variability and change on crop yield in Bulgaria. Agricultural and Forest Meteoroloy, 104, 315-327.

Alexandroy V, Eitzinger I (2005) The potential effect of climate change and eleyated air carbon dioxide on agricultural crop production in Central and Southeastern Europe. Fourzal of Crop Improtement, 13, 29l-331.

Allen GA, Pereira LS, Raes D, Sinith M (1998) Crop atopotranspiration: gujtelines for compusing srop water ripuiremests. Irrigation and Drainage Paper No. 56, FAO. Rome, Italy, F, 300.

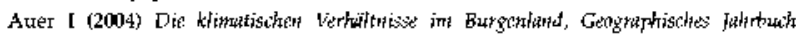
Burgenland 2004, Band 2S. Vereinigung Burgenländischer Geographen, PP. I1-25

Auer I, Korus E (2005) The variability of heat waves and dry spells in the lhat and mountainous regions of Austria, ICAM/MAP 2005. Croafian Meieorological jourmi, 40, 004-607.

Bartolini G, Morabito M, Crisci A ef al. (2008) Recent trends in Tuscany (Italy) summer temperature and indives of extremes. Infernational Jasrsal of Climatologis 28, I7511760 .

Battisti DS, Naylor RL (2009) Historical warnings of future food insecurity with umprecedented seasonal heat. Science, 9, 240-241.

Beniston M, Stephenson DB, Christensen OB et al. (2007) Future extreme events in European climate; an exploration of regional climate model projections. Climatic Cisange, 81, $7 \mathrm{I}-95$

Blombaick K, Eckersten $\mathbf{H}$, Sindhøj $\mathrm{E}$ ( 3009 ) Growth of golf turf as a furstious of tight asst

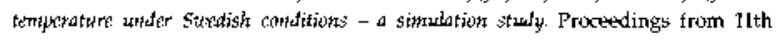
International Turf Grass Research Conference, Santiago, Chile, 26-31 July, 2009.

BrázJil R, Chromà K, Dobrovolný P, Tolasz R ( $(000)$ ) Climale fluctuations in the Czech Republic during the period 1901-2005. Internationat journal of Climatoloy 2, 2, 223-242.

Calanca P, Roesch A, Jasper K, Wild $M(2006)$ Global warming and the summertime evapotranspiration regime of the Alpine region. Climatic Chasge, 79, 65-78.

Cassman KG, Dobermann A, Walters DT, Yang HS (2003) Meting cereal demand while prodecting natural resources and improving environmental quality. Ammal Revicw of Environmest and Resources, 28, 315-358.

Chmielewski FM, Blümel K, Henniges Y, Müller A (2008) vulnerability of fruit growers to climate change. Observed impacts and assessment. Italian Journal of Agronony, 3, 605-606.

Chmielewski FM, Kohn W (2000) Impact of weather on yield and yield components of winter rye. Agriculture and Forest Metwrology, 102, 101-112.

Chmielewski FM, Müller A, Küchler W (2005) Possible impacts of climate change on natural regetation in Saxony (Germany). International Journat of Bimiefeorology. 50 . 96-104.

Christensen JH, Christensen $\mathrm{OB}$ (2007) A summary of PRUDENCE model projections of changes in European climate by the end of this century. Climatic Clsange, 81, 7-30.

Ciscar JC, Lylesias A, Feyen L ef at. (2009) Climate change impatits in Europk. Final Report of the PESETA Research Project, EUR 24093 EN, JRC Scientific and Technical Reports. Available at: http://ftp.jn:es/EURJoc/JRC55391.puff (acuessed 29 January 2011).

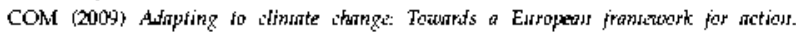
Commission of the European Communities, Brussels, 1.4.2009, COM(2009) 147 final, White Paper.

Cooper G, McGechan MB, Vinten JA (1997) The influence of a changed climate on soil workability and available works ays in Sootland. Joursal of Agridulfure Engiserists Research, 68, 253-269.

Dai A, Trenberth KE, Qian T (2004) A global data set of Palmer Drought Severity Index for 1870-2002: relationship with soil moisture and effects of surface warming. Journat of Hutrotogs 5, 1117-1130.

De Jongh ILM, verhoest NEC, De Troch FP (2006) Analysis of a 105-year time series of precipitation observed at Uocle, Belgium. Intersatiousal foursal of Climatology, 26. 2023-3039.

Dubrorsky M, Buchtole J, Zalud Z (2004) High-frequency and low-frecuency variability in stochastic daily wreather generator and its effect on agricultural and hydrologic modelling. Climatic Charsze, 63, 145-179.

Dubrovsky M, Nemesová I, Kalvova J (3005) Uncertainties in climate change scenariós for the Crech Republic. Climate Reserrcl, 29, 139-156.

Dubrovský M, Swotooda M, Trnka M, Hayes M, Wilhite D, Zalud Z, Hlavinka P (2009) Application of relative drought indices to assess climate change impact on drought conditions in Czechia. Theoretial and Appisud Climatology, 96, I55-171.

Easterling WE, Aggarwal PK, Eatima P of al. (2007) Food, fibre and forest products. Climate change 2007: impacts, adaptation and vulneratrility. Contritation of Working Group II. In: The Fouriss Assessmess Reporf of fise Intergozernmestal Pand ous Climatic Clsange (eds Parry ML, Canziani OF, Palutikof JP, van der Linden PJ, Hanson CE), pp. 273-313. Cambridge University Press, Cambridge 


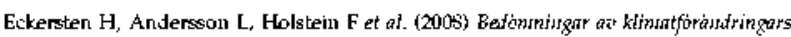

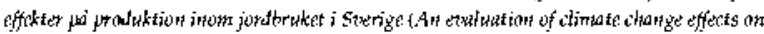
crop production in Suteden). Report No. 6, Department of Crop Production Ecology Swredish Univensity of Agricultural Sciences, Uppsala, Sweden, 145 Pp (in Swedish with English summary). Available at: hitp://www2.qpe.slu.se/VPEreport/ VPE $\% 20$ report $\% 20$ No\% 306 .pdf (accessed 29 January 2011).

Eitzinger J, Kersebaum KC, Formayer H (2009) Lastwirfsthaft in Kfimmoasted. Agrimedia, Clenze, Germany.

Eitzingzer J, Śtastná M, Zaalud Z, Dubrowskỵ M (2003) A simulation study of the effect of soil water balance and water stress on winter wheat production under different climate change scenarios. Agricultural Water Managemient, 61, 163-234.

Eliasson A. Terres JM, Eamps Cet al. (2007) Common bioptiysical criteria for defining areas which are less frowsrable for agriculture is Europe. Proceedings from the Expert Meting 19-20 April 2007. The Institute for Environment and Subtainability Joint Research Centre, Ispra, Italy, 93 pF.

Ewert F, Rounsevell MDA, Reginster I, Metzger MJ, Leemans R (2005) Future scenarios of European agricultural land use I. Estimating changes in crop productivity Agriculfure, Ecosystemis and Environtment, 107, 101-110.

FAO (1979) Yield Respourse to Water. Drainage and Irrigation Paper 33. FAO, Rome, Italy.

Finger $R(2010)$ Evidence of slowing yield growth - the example of Swiss cereal yields. Fond Policy, 35, 175-182.

Fischer G, Shah M, Tubiello FN it at. ( $(005)$ Socioreconomic and climate change impacts on agriculture: an integrated assessment, 1990-3080. Pisilosophical Traussictions of the Royal Socity B, 360, 2067-2083.

Fisher G, van Velthuizen, Shah H, Nachtergaele FO (2002) Glotral Agroevological Assessnent for Agriculfure in 21st Century; Mefhodology and Rusulis. ILASA, Laxenburg Austria.

Fronzek S, Carter TR (2007) Assessing unvertainties in climate change impacts on resource podential for Europe based on projections from $\mathrm{R} Q \mathrm{yls}$ and GOMs. Climatic Change, 81, 357-371.

Giorgi F, Lionello P (2008) Climate change projections for the Mediterranean region. Global and Plassiary Corange, 63, 90-104

Grifoni D, Mancini M, Maracthi G, Orlandini S, Zipoli G (2006) Analysis of Italian wine quality using freely available meteorological information. Amierican journal of Enclogy ass Vificulisre, 57, 339-346.

Gupta J, yan Asselt H, Amelung B et at. (2006) Climate Chargy Scientific disessment and

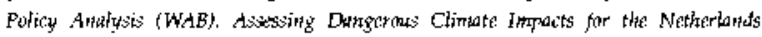
Netherlands Environmental Assessment Agency, Bilthoven.

Harvey LDD, Gregory J, Hoffert $M$ at al (1997) An Introduction to Simpte Climate Mondels Used in the IPCC Second Assessment Report. IPCC Tech Paper 2. Intergovernmental Panel on Climate Change, Geneva.

Hemniges Y, Vollmer I, Weber RWS, Görgens M, Clımielentrski FM (?007) Der Klimawandel, eine Herausforderung für den norddeutschen Obstbau. Mifteilungern des Obsitouzersuchsringes des Alfeus Landes, 62, 147-151.

Hlavinka P. Trnka M, Balek J $e$ al. (in press) Development and evaluation of SoilClim model for water balance and soil climate estimates. Agriculture Water Management, submittet.

Holden N, Brereton AJ, Fitzgerald JB (200S) Impact of climate change on Irish agricultural production systems. In: Climate Change in Iretand: Refining the Impasis (ed. Sweeney J). Pp. E2-I31. Irish Environmental Protection Agency, Johnstown Castle, Wexford.

Huglin P (1978) Nouveau mode d'evaluation des possibilités hèliothermicues de la vigne. Comptes Rerafus de l'Aladimis d'Agriculfure, Frastic, 1117-1126.

Hulme M, Wigley TML, Barrow EM, Raper SCB, Centella A, Smith S, Chipanshi AC (2000) Using a Climate Scenario Generator for Vulnerability and Adaptation Awessments: MAGICC and SCENGEN Version 2.4 Workbouk. Climatic Research Unit, Norwich.

IFPRI (2009) Climate change: impais on agriculture asd cosis of adaptation. Internal Report, $30 \mathrm{FP}$

Lylesias A (2009) Policy issues related to climate change in Spain. In: Policy and Strategic Belsariour in Water Rssource Massagensent (eds Dinar A, Albiac A), Pp. I45-174. Earthscan, London.

Gglesias A, Garrote L, Flores F, Moneo M (2007) Challenges to manaze the risk of water scarcity and climate change in the Mlediterranean. Water Risourwes Managensent, 21, 775-788.

Lglesias A, Garrole L, Quiroga S, Moneo M (in press-a) A regional comparison of the effects of climate change on agriculture in Europe. Climatic Chaszz, in press.

Lylesias A, Quiroga $S(2007)$ Measuring cereal production risk form climate variability across geographical areas in Spain. Climate Research, 34, 47-57.

Iglesias A, Quiroga S, Moneo M, Garrode L (in press-b) From climate change impacts to the development of allaptation strategies: challenges for agriculture in Europe Climatic Change, in press.
Iglesias A, Quiroga S, Schlickenrieder J (2010) Assessing unvertainty to support climate change adaptation needs for Mediterranean crops. Climute Resurch, 44, 83-94

Jacobeit J, Rathmann J, Philipf A, Jones PD (2009) Central European precipitation and temperature extremes in relation to large-scale atmospheric circulation types. Metwrologische Zeitsihrift, 18, $397-410$.

Jones GV, White MA, Cooper OR, Storchmann K (2005) Climate change and global wine quality: Clinsatic Clsause, 73, 319-343.

Jones PD, Lister DH, Jaggard KW, Pidgzon JD (2003) Future climate impact on the productivity of sugar beet (Beta inflyaris L.) in Europe. Climatic Change, 58, 93-108.

Jongman RHG, Bunce RGH, Metzger MJ, Mücher CA, Howrard DC, Mateus VL (2006) Objactives and application of a statisical environmental stratification of Europe. Lardsciupe Ecolory, 21, 409-419.

Kabat P, van Vierssen W, Verart J, Vellinga P, Aerts J (3005) Climate proofing the Netherlands. Nature, 438, 283-284.

Katerii N, Mastrorilli M, Cherni HE (2010) Effects of corn deficit irrigation and soil properties on water use efficiency. A. 25-year analysis of a Mediterranean environment using the STICS madel. Esropeas Joursal of Agronony, 32, I77-IS5.

Kenny GJ, Harrison PA (1993) Chapter I1. Analysis of effects of climate change on broadscale patterns of agrodimate in Europe. In: Thse Eiferf of Climati Clsarse an Agriculisral asd Horticulisral Potesfial is Esrope (ets Kenny GJ, Harrison PA, Parry ML), pF, 201-224. University of Oxford, UK.

Kimball BA, Kobayahsi $K$, Bindi M (2002) Responses of agricultural crops to free-air $\mathrm{CO}_{2}$ enrichment. Adzausus is Agrononsy, 77, 293-368

Klein Tank AMG, Wijngaard IB, Konnen GP (2002) Daily dataset of 204h-century surface air temperature and precipitation series for the European climate assessment. Intersatiosal joursal of Climatology, 22, I $111-1453$.

Kristensen K, Schelde K, Olesen JE (2011) Winter wheat yield response to climate variability in Denmark. Jourssal of Agricultural Science, 149, 33-47.

Kruijt B, Witte JPM, Jacobe CMJ, Kroon T ( $(008)$ Effects of rising atmospheric $\mathrm{CO}_{2}$ on evapotranspiration and soil moisture: a practical approach for the Netherlands. Journat of Hydrology, 349, 257-267.

Lancher W (2003) Physiclogical Plast Ecology 4th efn. Springer, Berlin

Layalle C, Micale F, Houston TD et at. (2009) Climate change in Europe. 3. Impact on agriculture and forestry. A review. Agronomity for Sustainatite Detwlopmicht, 29, 433-116.

Leenhardt D, Lemaire Ph (2002) Estimating the spatial and temporal distritation of sowing dabes for regional water management. Agriculturat Water Managcment, $\mathbf{5 5}$, $37-52$

Lobell DB, Burke MB, Tetaldi C, Mastrandrea MD, Falcon WP, Naylor RL (2008) Prioritizing climabe change adaptation needs for food security in 2030. Sicterce, 319, $607-610$

Lobell DB, Cassman KG, Field CB (2009) Crop yield gaps: their importance, magnihudes, and causes. Aminal Revienu of Emiromment and Resouris, 34, 179-204.

Maton L, Bergez JE, Leenhandt D ( $(0007)$ Modelling the days which are agronomically suitable for sowing maize. Estropern fousnal of Agrosomy, 27, 123-129.

Metzger MJ, Bunce RGH, Jongman RHG, Mücher CA, Watkins JW (2005) A climatic stratification of Europe. Global Ecology and Bicgeograpisy, 14, 549-563.

Mitchell TD, Hulme M (2002) Length of growing season. Weafhr, 57, 196-198.

Müller W (1993) Agroktimatische Kenmzeichnung des zentralen Marchfoldes. Beithefte tu den Jahrbüclsern der ZAMG Klimnatologie, H\&ft 3 . Zentralanstalt fuer Meteorologie und Geodynamik (ZAMG), Publ. No. 348, Wien

Nakicenovic N, Alcamo J, Davis G et al. (2000) Emisions Sicharios. A Sperial Report of

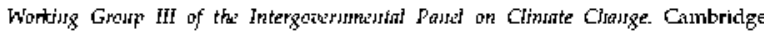
University Press, Cambridge.

Norrant C, Douguedroit A (2006) Monthly and daily precipitation trends in the Mediterranean. Throreticat and Ajplied Climatology, 83, 89-106.

Ntegeka V, Willems $\mathrm{P}(200 \mathrm{~s})$ Trends and multidecadal oscillations in rainfall extremes, based on a more than 100-year time series of 10 min rainfall intensities at Uccle,

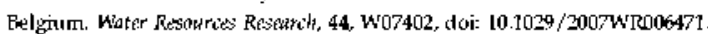

Olesen JE (2005) Climate change and $\mathrm{CO}_{2}$ effects on productivity of Danish agriculhural systems. Jountat of Coy Inifrmomient, 13, 257-274.

Olesen JE, Bindi M (2002) Consziquences of climate change for European agricultural productivity, land use and policy. Europian josrnal of Agrouroms, 16, 239-262

Olesen JE, Carter TR, Diaz-Ambrona CH at at. (2007) Uncertainties in projected impacts of climate change on European agriculture and ecosystems based on scenarios from regional climate madels. Climatic Clsange, 81, In-143.

Olesen JE, Trnka M, Kersetaum KC et al. (301) Risk assessment and foreseen impacts on agricultare. European Journal of Agromomy, 34, 96-112.

Parry ML, Rosenzweig C, Iglesias A, Livermore M, Fischer G (200N) Effects of climate change on global food production under SRES emissions and socio-economic scenarios. Global emvironmental Charngc, 14, 53-08. 
Peltonen-Sainio P, Jauhiainen L, Hakala K (2011) Crop responses to temperature and precipitation actording to long-term multi-location trials at high latitudes with reference to climate change. Fournol of Agriculture Science, 149, 49-62

Peltonen-Sainio P, Jauhiainen L, Laurila IP (2009) Cereal yield trends in northern European conditions: changes in yield potential and its realisation. Field Crops Researit, 110, 85-90

Peltonen-Sainio P, Rajala A, Känkänen H, Hakala K (2009b) Improving farming systems in northem European conditions. In: Crop Phusiology: Applications for Genetic Imatmemtent and dgromomy (eds Sadras vo, Calderini D), Fp. 71-97. Elsevier, Austendain, the Netherlands.

Playan E, Mateos L (2005) Modernization and optimization of irrigation systems to increase water productivity. Agricultuyal Water Manayemichi, 80, 100-116.

Porter JR, Semenov MA (2005) Crop responses to climatic variation. Philosephical Transictions of the Ruyal Sociely B, 360, 202I-2035.

Quiroga S, Iglesias A (2009) A comparison of the climate risks of cereal, citrus, grapevine and olive production in Spain. Agriculisral Systems, 101, 91-100.

Ramankutty N, Foley JA, Norman J, Mcsweeney K (2002) The global distribution of cultivable lands: current patterns and sensitivity to possible climate change. Gtobal Eiology and biogegraphy, 11, 377-392.

Reidsma P (2007) Adaptation to Climate Clausz: Europern Agriculisur. PhD Thesis, Wageningen University, the Netherlands, 204 pP.

Reidsma P, Ewrert F, Boogaard H, van Diepen K (2009) Regional crop modelling in Europe: the impact of climatic conditions and farm characteristics on maize yields. Agriculture Stystemts, 100,51-60

Robinson J (ed.) (2006) 'Bulgism'. Oxford Companios to Wine. ISBN 0-19-860990-6, Third Edition ed. Oxiford University Press, Oxford, pp. 75-76.

Rochette P, Belanger G, Castonguay $\Upsilon$, Ewoulsma A, Mongrain D (2004) Climate change and winter damage to fruit trees in Eastern Canada. Grnatian jourssal of Plass Sience, 81, I113-1125.

Rotter R, Palosio T, Salo T at at. (2009) What would happen to barley production in Finland if global temperature increases above $4 \mathrm{C}$ ? A model-based assebsment. In:

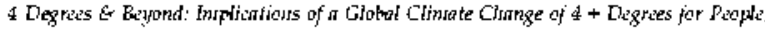
Ecoststems and the Earth-Systemi, International Climate Conference, 28-30 Scptember 2009: Atstract Bowk, pp. 19-25. University of Oxford, Oxford

Rötter R, van Diepen CA (1994) Nrime Basin Study: tast drse projections borsed as

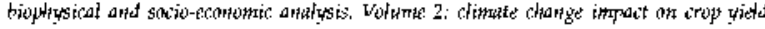
potentials and twater ws. Report 85.2, SC-DLO and RLZA, Wayeningen, the Netherlands, 152 $\mathrm{PP}$.

Rounsevell MDA (1993) A review of soil workability models and their limitations in temperate regions. Soil use and Marnayentent, 9, 15-21.

Samnondisk planteforedling (1992) Agroldimatisk kartleggisg av Norden Agrovimatic napping of Nordess. Skrifter och rapporter, no. 5, 97 pp.

Santer BD, Wigley TML, Schlesinger ME, Mitchell JFB (1990) Dertoloping dimtate siessarios from equilibrium GCM resulis. Report No. 47, Max Planck Institut für Meteorologie, Hamburg

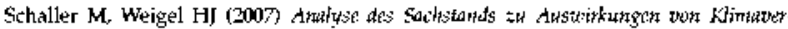

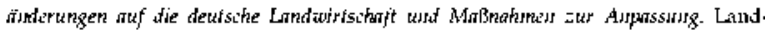
bauforschung Volkenrode, Special Issue 3T6, Braunschrweig, Germany, $247 \mathrm{pP}$.

Schultz HR (2000) Climate change and viticulture: an European perspective on climatology, carbon Jioxide and UV-B effects. Ausimitian journat of Grape asd Wime Resuarcis, 6, 2-12.

Schultz HR, Hoppmann D, Hofmann M (2005) Der Einfthss klimatischey Verditerungen

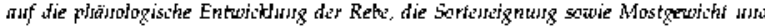
Sasurestrukfur der Trasiben. Report for the InKlim 2012 program, Feteral environmental Agency, Hesse. Available at: http://www.hlug,de/Hatic/klimawandel/ inklim/dokumente/endberichto/weinbau.pdf (accessed 29 January 2011).

Seguin B, Garcia De Cortazar I (2005) Climate urarming: consequences for viticulture and the notion of terroirs in Europe. Actu Horticulturac, 689, $61-71$.

Seneviratne SI, Lüthi D, Litschi M, Schär $\mathrm{C}\left(3000^{\circ}\right)$ Land-atmosphere coupling and climate change in Europe. Nafure, $\mathbf{4 3}, 205-309$

Simota $C(3009)$ Quantitative assessment of some adaptation measures to climate changes for arable crops. In: Impact of Climate. Change and daptation in Agriculture.

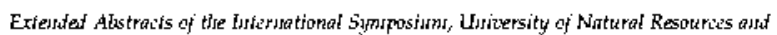

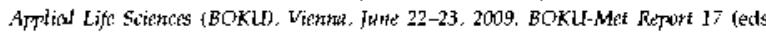
Eitzinger J, Kutu G), pp. 22-25. BOKU, Vienna, Austria. Available at: http:// urww.boku.ac.at/met/report (aocessed 29 January 3011 ).

Skjelvà AO (1998) Climatic conditions for crop production in Nordic countries. Agricultural and Fond science in Fintart, 7, 149-100.

Smit HJ, Metzger MJ, Ewert F ( 0008 ) Spatial distribution of grassland productivity and land use in Europe. Agricultuye Systems, 98, 208-219.

Solomon S, Qin D, Manning M at al. (eds) (2007) Climate Change 2007: The Plysical Sisence Basis. Contribution of Working Group I to fise Fourith Assessnsent Riport of tha Intergovernmental Pant on Climbte Change. Cambridge University Press, Cambridge

Stock M, Gerstengarbe FW, Kartschall T, Werner PC (3005) Reliability of climate change impact assessments for viticulture. Acta Horisiditume, 689, 29-40.

Torssell B, Eckersten H, Kornher A, Nyman P (3008) Radiation use and uptake of mineral $\mathrm{N}$ in ley under climatic change. Grasiband sience in Europer, 13, $335-340$.

Trnka M, Dubrovsky M, Semerajova D, Zalud Z ( $(00 \mathrm{~N})$ Projections of uncertainties in climate change scenarios into expected winter wheat yields. Theoretical and Afpitid Climatology, 77, 229-249.

Truka M, Eilzinger J. Dubrovsky $M$ af al. (2010a) Is the rainfed crop production in central Europe at risk? - using a regional climate model to produce high resolution agroclimatic information for decision makers. Joursal of Agricuituri Sciesce, 148. 639-656.

Tmka M, Kocmankova E, Ealek J at at. (2010b) Simple snow cover model for agrometeorological applications. Agricultumal ass Forest Meteorology, 150, 1115-1127.

Truka M, Kysely J, Mơný M, Dubrouský M (2009) Changes in Central-European soilmoishure availability and circulation patterns in 1881-2005. International foumal of Climatology, 29, 655-67?

van der Schrier G, Briffa KR, Jones PD, Osborn TJ (2006) Summer moisture variability across Europe. Justral of Climate, 19, 28IB-2834

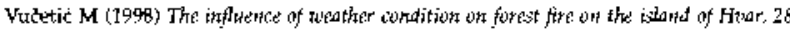
Juhy-4 August 1997. III. International Conferenve on Forest Fire Research, Vol. I, Luso, Porkugal, 16-20 November 1998, Fp. 1295-1303.

Vucetic M, Vučetic V, Spanjol Ž, Barčic D, Rosavec R, Mandić A (2006) Secular variations of monthly severity rating on the Croatian Adriatic coast during the forest fire season. Forest Ecoloyy and Maraycement, 294 (Suppl. 1), 25 L-26l.

Vucetic V, Vucetic $M(\mathbf{2 0 0 0})$ The role of climatic variations on the establishment of the Adriatic marine parke. Pericuficum Biclogorum, 102 (Suppl. 1), 489-498.

Wechsung F, Gerwengarte FW, Lasch P, Lültger A (2008) Dis Ertragsfiathigted wotdeutscher Ackerflächer untey Klimanandet. PIK Report 112, Polsdam Institute for Climate Change Impact Research, 93 PP.

Zanis P, Kapsomenakis I, Philandras $C$ af at. (2009) Analysis of an ensemble of present day and future regional climate simulations for Greece. International foumal of Climatology, 29, 1614-1633.

\section{Supporting Information}

Additional Supporting Information may be found in the online version of this article:

Appendix 51: List of the 86 sites used in the study.

Please note: Wiley-Blackwell are not responsible for the content or functionality of any supporting materials supplied by the authors. Any queries (other than missing material) should be directed to the corresponding author for the article. 